\title{
Cultura organizacional e vivências de prazer e sofrimento no trabalho: um estudo com professores de Instituições Federais de Ensino Superior
}

\section{Organizational Culture and Experiences of Pleasure and Suffering at Work: A Study With Teachers From Federal Institutions of Higher Education}

\author{
VANUSA CRISTINA DARIO* \\ MARIANE LEMOS LOURENÇO**
}

\section{RESUMO}

Este trabalho busca analisar como a cultura organizacional se entrelaça às vivências de prazer e sofrimento no trabalho de professores de Instituições Federais de Ensino Superior. Tal problematização foi motivada pela escassez de estudos sobre as relações entre a cultura organizacional e seus elementos, com as vivências de prazer e sofrimento dos trabalhadores. A pesquisa qualitativa se deu por meio de entrevistas com 20 docentes de duas Instituições Federais de Ensino Superior. Os dados obtidos revelam que as vivências de prazer desses docentes estão relacionadas com a própria atividade da docência e o relacionamento com os alunos. Já as vivências de sofrimento no trabalho estão relacionadas também com os alunos, mas principalmente ao relacionamento conflituoso entre pares e chefias. Observou-se ainda o impacto da atividade docente nas esferas familiar e social, e o impacto na saúde dos docentes. O contexto organizacional, e

* Universidade Federal do Paraná. Mestranda em Administração pela UFPR. vanusadario@ hotmail.com .

** Universidade Federal do Paraná. Doutora em Psicologia pela USP. Mestre em Psicologia pela USP. Graduação em Psicologia pela UFPR. psimari@uol.com.br . 
a gestão das instituições também foram apontados como fontes de sofrimento no trabalho. Espera-se com este estudo contribuir para o entendimento das vivências de prazer e sofrimento no trabalho, ao fornecer dados que propiciem a melhoria das práticas organizacionais e de gestão de pessoas dentro das organizações. Palavras-chaves: Cultura organizacional. Psicodinâmica do trabalho. Prazer e sofrimento no trabalho. Adoecimento no trabalho.

\section{Abstract}

This study examined how organizational culture intertwines the experiences of pleasure and suffering at work among professors in federal institutions of higher education. This investigation was motivated by the lack of studies on the relationship between the organizational culture and its elements and the experiences of pleasure and suffering among staff. The qualitative research was done through interviews with 20 teachers from two institutions of higher education. The data showed that the experiences of pleasure among these teachers were related to the activity of teaching itself and their relationships with students. Their experiences of suffering at work were also related to students, but particularly resulted from conflicted relationships with their peers and superiors. The impact of teaching on the family and social spheres was also noted, along with impacts on the professors' health. The organizational context and management at the institutions were also indicated as sources of suffering at work. We hope to add to understanding about the experiences of pleasure and suffering at work by providing data that lead to improved organizational and management practices among people within the organizations.

Key-words: Organizational culture. Psychodynamics of work. Pleasure and suffering at work. Illness at work.

\section{INTRODUÇÃO}

A abordagem teórica da psicodinâmica do trabalho contribui, de maneira efetiva, na realização de estudos sobre a organização do trabalho, as relações entre saúde e trabalho, e as discussões acerca das vivências de prazer e sofrimento nas organizações, entre outras temáticas, pois se trata de uma vertente que fornece um quadro teórico sólido para os estudos a respeito dos aspectos psíquicos, sociais e subjetivos dos indivíduos em face da organização do trabalho (ARANTES, 2015). 
Especificamente com relação ao trabalho docente, os aspectos psicopatológicos relativos às condições de trabalho e à saúde mental desses trabalhadores, têm sido recentemente abordados em produções científicas. Por exemplo, dentro da área de Estudos Organizacionais, após pesquisa nas bases dos periódicos A2, B1 e B2 da área, foram encontrados 10 artigos que abordam as interfaces entre prazer e sofrimento dos professores, nos últimos dez anos.

Contudo, a saúde do professor é um debate que se torna cada vez mais necessário, pois se trata de uma categoria profissional propensa a sofrimento psíquico. De acordo com essa premissa, Freitas (2007), argumenta que a academia é um lugar de risco para a saúde dos professores, visto a frequência das doenças psicossomáticas que os acometem, sendo alguns dos males mais diagnosticados a gastrite, taquicardia, hipertensão, irritabilidade, insônia, depressão, síndrome do pânico, estresse e síndrome do esgotamento profissional (burnout). Ainda as cobranças excessivas, a compressão do tempo, a competição ferrenha, e a contínua atualização tecnológica e da área de estudos, dão origem a uma fadiga institucional que coloca "a carreira docente como uma das mais estressantes do mercado". (FREITAS, 2007, p. 190).

A partir disso, propor um estudo sobre a cultura organizacional e as vivências de prazer e sofrimento no trabalho de docentes surgiu como uma proposta que pudesse trazer o professor universitário para o cenário das pesquisas como sujeito pesquisado, buscando não somente a contribuição teórica, mas também uma forma de sensibilizar as instituições de ensino para as condições de trabalho que estas oferecem aos seus docentes. Diante dessas perspectivas, a pesquisa busca analisar como a cultura organizacional se entrelaça às vivências de prazer e sofrimento no trabalho de professores de Instituições Federais de Ensino Superior - IFES.

Quanto à contribuição prática deste trabalho, a intenção principal está em chamar a atenção para as consequências do sofrimento psíquico vivenciado pela pessoa em seu espaço de trabalho, que pode levar a afastamentos por motivo de adoecimento, licenças de médio e longo prazo, e até mesmo aposentadorias compulsórias, no caso de servidores públicos (AUGUSTO; FREITAS; MENDES, 2014). 
Além disso, para Araújo et al. (2016), o sofrimento psíquico vivenciado pela pessoa em seu espaço de trabalho reflete em todas as áreas de sua vida, no relacionamento familiar, com os amigos e, principalmente, em sua saúde física e mental.

Assim, analisar como a cultura organizacional pode permear os processos de prazer e sofrimento no trabalho, para minimizar prejuízos humanos e sociais nas organizações, com destaque especial ao trabalho docente, parece um caminho promissor para futuros estudos organizacionais, a fim de contribuir para a construção de um cenário mais favorável às organizações, em termos de produtividade, e principalmente, para as pessoas, em termos de saúde e satisfação com o trabalho realizado.

\section{REFERENCIAL TEÓRICO}

Neste referencial teórico, são apresentadas reflexões acerca da cultura organizacional e cultura organizacional brasileira. No item posterior, é trazida a abordagem da Psicodinâmica do Trabalho, e em seguida a caracterização do trabalho docente no Brasil.

\subsection{Cultura organizacional e cultura organizacional brasileira}

O termo cultura tem sua origem atribuída à Antropologia, onde os estudos de Geertz (1989) se destacam. Na tentativa de uma integração de interpretações, o autor propõe duas ideias principais. A primeira é de que a cultura seria um conjunto de mecanismos de controle, como planos, receitas, regras, instruções, para governar o comportamento. A segunda, seria que o homem é dependente de tais mecanismos de controle desses padrões culturais, para ordenar o seu comportamento. Ou seja, na primeira visão a cultura agencia e controla o comportamento humano. Na segunda visão, o homem constrói seu comportamento, com a finalidade de adequar-se, ou não, ao padrão cultural existente. Para Geertz, concordando com Max Weber, o homem estaria amarrado a teias de significados que ele mesmo teceu, assumindo a cultura como sendo essas teias e a sua análise; portanto, não como uma ciência experimental em busca de leis, mas como uma ciência interpretativa, à procura do significado (GEERTZ, 2008, p. 4). 
Dentro dessa temática, Berger e Luckman (1998), com a intenção de explorar o processo de elaboração do universo simbólico, discorrem acerca de como a realidade é percebida pelos indivíduos, construída socialmente, e como se dá o processo de legitimação das regras instituídas pelos grupos. Para esses autores, os indivíduos, por meio de processos como o aprendizado, a linguagem e as tradições, passam a compreender a realidade à sua volta e compartilhar essa realidade com os outros. Por intermédio desses mesmos processos, as sociedades legitimam as atitudes consideradas corretas dentro de determinado grupo, assim como não aceitam as consideradas incorretas, e punem os seus transgressores. Ao encontro dessa perspectiva, Fleury e Fischer (1996) afirmam que os indivíduos percebem a existência da correspondência entre os significados atribuídos aos objetos e os compartilham entre si, criando nos grupos um senso comum sobre a realidade.

Assim, ancorado principalmente no conceito da realidade socialmente construída, Morgan (1998), ao falar de cultura, refere-se tipicamente ao padrão de desenvolvimento refletido nos sistemas sociais de conhecimento, ideologia, valores, leis e rituais cotidianos, e ao considerar as organizações como culturas, afirma que estas assumem o papel de mini sociedades, com seus valores, rituais, ideologias e crenças próprias. Para o autor, a criação da realidade organizacional se dá por meio de valores, crenças, significados e interpretações comuns aos participantes daquela organização.

É importante frisar que a cultura organizacional é percebida por meio de seus elementos, como um conjunto de representações imaginárias sociais, que se constroem e reconstroem nas relações cotidianas dentro da organização, e que se expressam em termos de valores, normas, significados e interpretações, visando um sentido de direção e unidade, tornando a organização fonte de identidade e de reconhecimento para os seus membros (FREITAS, 2006).

Para que seja possível analisar como tais elementos podem ter significado no cotidiano dos indivíduos, é preciso identificá-los. Para isso, Fischer e Mac-allister (2001) afirmam que alguns dos elementos que constituem a cultura organizacional são: liderança, valores, símbolos, mitos, lendas, sagas, anedotas, crenças, estruturas, 
hábitos, linguagens, ritos, cerimônias, regras sociais, normas, credos, filosofias de gestão, saber compartilhado etc.

A respeito disso, Morgan (1998) afirma que as organizações tendem a refletir as características culturais da nação onde estão estabelecidas, e nesse sentido, conforme apontado por Motta e Caldas (1997), toda sociedade, em maior ou menor medida, reflete costumes e valores à sua própria maneira na cultura organizacional. Assim, os costumes, crenças, valores, e também os artefatos que caracterizam a cultura de uma organização trazem de alguma forma os traços da cultura nacional, não sendo possível estudar a cultura das organizações que operam em uma sociedade, sem estudar a cultura dessa sociedade.

Para a análise dos dados obtidos neste trabalho, será de fundamental importância uma reflexão acerca dos traços da cultura brasileira, e da cultura organizacional brasileira. Acerca disso, para Freitas, A. B. (1997), a influência da cultura nacional a respeito da cultura organizacional é visível, e se a "cultura organizacional carrega muito de nossa cultura nacional, a compreensão de nossas raízes se torna um ponto crucial no gerenciamento de nossas organizações" (FREITAS, A. B., 1997, p. 39).

Nesse sentido, a cultura brasileira tem sido tema de tentativas de interpretação, e com esse objetivo, muitos estudos buscam compreender os traços da cultura brasileira, com base em trabalhos que analisam a formação histórica, cultural, social e econômica do país (CHU; WOOD, 2008).

Um desses estudos tidos como referência nessa temática é o de Holanda (1989). Em sua obra Raízes do Brasil, o autor detalha algumas características da cultura brasileira, onde uma forma de caracterizar o brasileiro é definida como "o homem cordial", que tem a informalidade com relação às regras, relações sociais e políticas, como uma característica marcante, que teve sua origem na colonização do Brasil, e dos sistemas dele herdados, como o patriarcalismo e o coronelismo. Para o autor, nesses sistemas a noção de privilégios a favor de pessoas próximas é muito presente, e também a apropriação do bem público como uma extensão da vida privada, em que os favoritismos têm espaço e estão acima do bem maior. Essa 
intimidade proposta pelo homem cordial é também caracterizada pelo que o autor chama de "o jeitinho brasileiro".

Contudo, é preciso deixar claro que o trabalho de Holanda (1989) não abrange todos os traços nacionais brasileiros. Nesse sentido, os estudos de Motta e Caldas (1997) trazem uma importante contribuição para o entendimento dos traços da cultura brasileira mais nitidamente influentes no âmbito organizacional brasileiro.

Para Motta e Caldas (1997), o "jeitinho" estaria próximo da malandragem, mas as duas coisas ainda seriam diferentes. $\mathrm{O}$ “jeitinho brasileiro" seria uma prática cordial que implica personalizar relações por meio da descoberta de um time de futebol comum ou de uma cidade natal comum, ou ainda de um interesse comum qualquer. É diferente da arrogância em apelar para um status mais alto de um parente ou de um conhecido importante. Porém, para o autor, as duas coisas são frequentes em nosso país e, por vezes, aparecem habilmente combinadas. Já a malandragem implica a predisposição para tirar vantagem, passar para trás e, eventualmente, enganar, o que o "jeitinho" não tem.

Destaca-se, neste trabalho, a contribuição de Freitas, A. B. (1997), que traz para esta análise algumas das características chave da cultura brasileira, entre elas o personalismo e o autoritarismo, que são detalhados a seguir.

O personalismo, por ser a sociedade brasileira ancorada em relações, desenvolve-se nas pessoas, e é caracterizado pela necessidade de tornar seus relacionamentos mais próximos e afetuosos. No entanto, há uma contradição nessa sociedade hierarquizada que, ao mesmo tempo, busca proximidade em suas relações. Isso revela que a unidade básica da cultura brasileira não está no indivíduo, mas na relação. O que vale aqui não é o cidadão, mas a malha de relações estabelecidas por pessoas, famílias e grupos de pares e amigos. A relação perverte e cria variações da cidadania, hierarquizando e criando níveis de proximidades do centro do poder. O brasileiro sabe, por exemplo que, ao ingressar em uma organização, deve logo arrumar um bom "padrinho". Por meio de suas relações mais próximas do poder, o "padrinho" representa a trilha rumo à rápida ascensão até o topo da organização. Isso se reflete também na esfera pública onde, muitas vezes, a escolha de pessoas que exercerão 
funções públicas faz-se de acordo com critérios de relações pessoais e não de suas capacidades (FREITAS, A. B., 1997; HOLANDA, 1989; DAMATTA, 1991).

Outro traço marcante da gestão no Brasil é o autoritarismo. As pessoas comportam-se de maneira predominantemente submissa e fazem o que lhes é dito para fazer. Há pouco desafio a ordens e excesso de respeito à autoridade. Ainda segundo os relatos, as decisões no país tendem a caminhar para o consenso, pois há muito medo do confronto, ausência de críticas e pontos de vistas dissidentes, revelando grande tendência à aversão ao conflito (CHU; WOOD, 2008; BARROS; PRATES, 1996).

Apesar de convergirem em muitos aspectos, os estudos sobre a cultura organizacional brasileira não são unânimes em seus resultados. Um fator determinante para isso, segundo Alcadipani e Crubellate (2003), é de que a maioria dos estudos sobre cultura brasileira, desenvolvidos no âmbito da administração, analisa o tema de forma homogênea, não levando em conta a pluralidade e a heterogeneidade do país e das organizações. Os autores questionam a apresentação da cultura organizacional brasileira como claramente decifrável, com traços facilmente evidenciados, pelo simples fato de estarem dentro das fronteiras geográficas de um mesmo país. Para eles, essa noção de cultura funcionaria como uma "infraestrutura, condicionando todas as organizações, e aceitaria um princípio de causalidade simples" (ALCADIPANI; CRUBELLATE, 2003, p. 72).

Por conseguinte, para Freitas (1991), no Brasil o tema cultura organizacional é, ainda, tratado de maneira bastante secundária. Concordando com essa visão, Fischer e Mac-Allister (2001) afirmam que os estudos sobre cultura organizacional brasileira estão remetidos à fragmentação e descontinuidade, o que pode resultar em modismos, ou estudos superficiais, e que é necessária uma comunidade de discurso interessada nos estudos sobre cultura, voltados para as organizações brasileiras, reconhecendo suas peculiaridades locais e regionais. Assim, utilizando as palavras de Freitas (2007b) "é preciso ter clareza de que o conceito de cultura não é universal, tampouco inequívoco" (FREITAS, 2007b, p. 11). 
Para dar início à temática referente às relações entre homem e trabalho, a abordagem da psicodinâmica do trabalho é apresentada a seguir.

\subsection{Psicodinâmica do trabalho}

O prazer e o sofrimento no trabalho vêm sendo estudados por Dejours (1992, 2006, 2007, 2012), articulados à organização do trabalho, e tendo como consequências impactos no funcionamento psíquico dos trabalhadores, dependendo do quanto as relações estabelecidas com o trabalho são consideradas satisfatórias, ou não (MENDES; TAMAYO, 2001). Assim, por meio da dialética prazer e sofrimento no trabalho, tem-se procurado identificar como os indivíduos gerenciam essas situações dentro do seu cotidiano de trabalho, e buscam manter sua saúde física e mental.

A psicodinâmica do trabalho teve seu início com o médico do trabalho, psiquiatra, e psicanalista francês Christophe Dejours, na década de 1980, com a publicação de Travail: usure mentale. Essai de psychopathologie du travail (traduzido no Brasil sob o nome de A Loucura do Trabalho: estudo de psicopatologia do trabalho) em 1987. Entre seus conceitos principais, o sofrimento criativo e o sofrimento patogênico, a psicodinâmica do trabalho busca trazer para as organizações o conhecimento das consequências individuais e sociais do sofrimento humano no trabalho (DEJOURS; ABDOUCHELI; JAYET, 2012).

Do ponto de vista psicológico, o trabalho provoca diferentes graus de motivação e de satisfação no trabalhador, principalmente quanto à forma e ao meio no qual desempenha sua tarefa. Há que se considerar também a importância do trabalho no destino individual, evidenciando, inclusive, sua importância como fator de equilíbrio psicológico. É possível atestar que, fora as condições de sobrevivência e subsistência, "o trabalho possibilita ao indivíduo exercer sua potencialidade criativa, desde que as condições ambientais e profissionais sejam facilitadoras, levando-o à plena realização, do contrário, o trabalho que pareça sem sentido, tende a levar o indivíduo à frustração" (ALTHUSSER, 1994, p. 19).

Assim, a organização do trabalho, caracterizada pelo conteúdo da tarefa e relações socioprofissionais, exerce um impacto no fun- 
cionamento psíquico do trabalhador, gerando prazer ou sofrimento. Contudo, o que determinará o prazer ou o sofrimento no trabalho depende do quanto a tarefa é significativa para o trabalhador e se as relações com colegas e chefias são ou não de reconhecimento, cooperação, confiança e solidariedade (VAZQUEZ; BASTIANELLO, 2011; SCHUJMANN; COSTA, 2011).

Nesse sentido, Mendes e Tamayo (2001) afirmam que o prazer e o sofrimento inscrevem-se numa relação subjetiva do trabalhador com o seu trabalho, que implica intersubjetividade no momento em que esse sujeito passa a relacionar-se com outros, sendo os valores, como princípios que guiam a vida da organização, um dos elementos responsáveis pela socialização das normas e regras, que definem formas específicas do trabalhador vivenciar sua tarefa e compartilhar suas relações sociais, afetivas e profissionais no contexto organizacional.

Já para Rocha, Mendes e Morrone (2012), o trabalho contém vários elementos que influenciam a formação da autoimagem do trabalhador que, por sua vez, é razão para o sofrimento. Como mediador do processo de saúde, o trabalho constitui-se fonte de prazer por possibilitar a realização e a construção da identidade dos sujeitos. Por sua vez, apresenta características promotoras de sofrimento, especialmente quando não promove o reconhecimento do trabalho realizado, e a vivência de prazer.

Nesse sentido, na concepção de Dejours (1992), a organização do trabalho pode desencadear o sofrimento psíquico nos indivíduos durante o processo de execução das suas tarefas. Esses conflitos, muitas vezes, são resultantes das tentativas de adaptação entre a organização e o desejo individual. A organização do trabalho exerce uma ação sobre o indivíduo, afetando o aparelho psíquico, criando um bloqueio na relação homem/trabalho. Por esse motivo, Dejours (1992) afirma que o sofrimento começa quando "a relação homem e organização do trabalho está bloqueada, quando o trabalhador usou de tudo de que dispunha na organização do trabalho, e quando ele não pode mais mudar de tarefa" (DEJOURS, 1992, p. 52). Fala-se então de sofrimento patogênico.

A respeito do sofrimento patogênico, Dejours (2013) inicia seus estudos analisando os efeitos das organizações do trabalho inspira- 
dos ou derivados do taylorismo sobre a saúde dos trabalhadores, e percebe que a grande consequência da organização científica do trabalho, sobre a saúde mental dos trabalhadores, é a criação de uma clivagem entre o corpo e o pensamento, a ponto de os trabalhadores chegarem a lutar contra sua própria atividade de pensar espontânea, porque a última tende a desorganizar sua atividade, a perturbar suas cadências e a ocasionar erros. Isso leva o trabalhador a recorrer a estratégias defensivas muito particulares: o objetivo do trabalhador, incomodado pela sua atividade psíquica espontânea, consiste não em descartar a última, mas em paralisá-la. Para tanto, a maioria dos trabalhadores acelera o ritmo do trabalho. O trabalhador se engaja freneticamente na aceleração, de maneira a ocupar todo o seu campo de consciência com uma sobrecarga de trabalho. Com a ajuda então da fadiga, "o trabalhador chega a paralisar seu funcionamento psíquico" (DEJOURS, 2013, p. 162).

Contudo, de acordo com Brant e Gomez (2004), é importante reconhecer que o sofrimento não tem uma manifestação única para todos os indivíduos de uma mesma família, cultura ou período histórico. O que é sofrimento para um, não é, necessariamente, para outro, mesmo quando submetidos às mesmas condições ambientais adversas. Ou ainda, aquilo que é sofrimento para alguém, pode ser prazer para outro e vice-versa. Um acontecimento, como algo capaz de provocar um espanto, em determinado momento pode significar sofrimento; em outro, pode ser vivenciado como satisfação.

Para Dejours e Abdoucheli (2012), o sofrimento patogênico aparece quando todas as margens de liberdade na transformação, gestão e aperfeiçoamento da organização do trabalho já foram utilizadas. Quando não há nada além de pressões fixas, rígidas, incontornáveis, inaugurando a repetição e a frustração, o aborrecimento, o medo, ou o sentimento de impotência. Quando foram explorados todos os recursos defensivos, o sofrimento residual, não compensado, começa a destruir o aparelho mental e o equilíbrio psíquico do sujeito, empurrando-o lentamente, ou brutalmente, para uma descompensação mental ou psicossomática, e para a doença.

Ferreira e Mendes (2001) mencionam que as pesquisas de Dejours $(1992,2007,2012)$ revelam que situações de medo e de tédio são responsáveis pela emergência do sofrimento, que se reflete em 
sintomas como a ansiedade, e a insatisfação. Apontam ainda para a relação entre esses sintomas e a incoerência entre o conteúdo da tarefa e as aspirações dos trabalhadores; a desestruturação das relações psicoafetivas com os colegas; a despersonalização com relação ao produto; frustrações e adormecimento intelectual. Dessa forma, o sofrimento é capaz de desestabilizar a identidade e a personalidade, conduzindo a problemas mentais. Para esses mesmos autores, as vivências de sofrimento aparecem associadas à divisão e à padronização de tarefas com subutilização do potencial técnico e da criatividade; rigidez hierárquica, com excesso de procedimentos burocráticos, ingerências políticas, centralização de informações, falta de participação nas decisões e não reconhecimento; e pouca perspectiva de crescimento profissional (FERREIRA; MENDES, 2001).

Há que se citar, ainda, o sofrimento pelo medo de não satisfazer, de não estar à altura das imposições da organização, como imposição de horário, de ritmo, de formação, de informação, de aprendizagem, e de adaptação à cultura ou à ideologia da empresa, às exigências do mercado, às relações com os clientes, os particulares ou o público, como fatores que levam ao sofrimento patogênico (DEJOURS, 2012).

Porém, para Dejours e Abdoucheli (2012), quando o sofrimento pode ser transformado em criatividade, ele traz uma contribuição que beneficia a identidade, aumenta a resistência do sujeito ao risco de desestabilização psíquica, e somática, o trabalho funciona, então, como um mediador para a saúde dos trabalhadores. Pesquisas feitas por Mendes (1995,1999), e Mendes e Abrahão (1996), indicam que o prazer é vivenciado quando o trabalho favorece a valorização e o reconhecimento, especialmente, pela realização de uma tarefa significativa e importante para a organização e a sociedade. O uso da criatividade e a possibilidade de expressar uma marca pessoal também são fontes de prazer e, ainda, o orgulho e admiração pelo que se faz, aliados ao reconhecimento da chefia e dos colegas.

Para Ferreira e Mendes (2001), a valorização é o sentimento de que o trabalho tem sentido e valor em si mesmo, é importante e significativo para a organização e a sociedade. O sentimento de reconhecimento significa ser aceito e admirado no trabalho e ter liberdade para expressar sua individualidade. Para Dejours (2012), 
o bem-estar, ou o prazer no trabalho, resulta da descarga de energia psíquica que a tarefa autoriza, o que corresponde a uma diminuição da carga psíquica negativa do trabalho. A partir disso, os fatos tornam-se mais simples para serem interpretados: "se um trabalho permite a diminuição da carga psíquica, ele é equilibrante. Se ele se opõe a essa diminuição, ele é fatigante" (DEJOURS, 2012, p. 25).

Ainda, segundo Dejours (2012), o trabalho livremente escolhido ou organizado oferece vias de descarga da carga psíquica: o trabalho torna-se, então, um meio de relaxamento, sendo chamado de trabalho equilibrante. Assim, a carga psíquica do trabalho aparece como um regulador da carga global de trabalho. Em geral, a carga psíquica do trabalho aumenta quando a liberdade de organização do trabalho diminui, abrindo espaço para o domínio do sofrimento nas vivências dos trabalhadores.

Para Ferreira (2012), é importante identificar os aspectos que possam identificar a face do prazer relacionado ao trabalho. Para o autor, o trabalho como fonte de prazer engloba as capacidades humanas do sentir, do pensar e do fazer. Sendo que essas três esferas estão articuladas com as vivências de bem-estar, alegria e satisfação em relação ao trabalho.

Ainda, para Ferreira (2012), existem duas condições interdependentes, relacionadas com o fator "organização do trabalho", e que tornam o trabalho fonte de prazer. A primeira, diz respeito à possibilidade real de executar o trabalho sem pressão de qualquer natureza (chefia imediata), e sem excesso de atividades (sobrecarga de tarefas). A segunda, trata dos riscos presentes nas situações de trabalho, onde o trabalho é considerado como fonte de prazer quando não oferece riscos para a saúde, a segurança pessoal, e a própria família (FERREIRA, 2012, p. 112).

Para a caracterização do contexto empírico desta pesquisa, é apresentado, a seguir, o trabalho docente entre prazer e sofrimento, tendo como base outros estudos realizados com a mesma temática.

\subsection{O trabalho docente entre prazer e sofrimento}

Com relação à temática, Freitas (2007a) argumenta que a academia é um lugar de risco para a saúde dos professores, visto a frequência das doenças psicossomáticas que os acometem. A autora 
destaca alguns dos males mais diagnosticados, como gastrite, taquicardia, hipertensão, irritabilidade, insônia, depressão, síndrome do pânico, estresse e síndrome do esgotamento profissional (burnout). Ainda, de acordo com a autora, com exceção da sala de aula e do relacionamento com os alunos considerados gratificantes, as cobranças excessivas, a compressão do tempo, a competição ferrenha, e a contínua atualização tecnológica e da área de estudos dão origem a uma fadiga institucional que coloca "a carreira docente como uma das mais estressantes do mercado" (FREITAS, 2007a, p. 190).

Muitos estudos sobre o trabalho docente se referem à Síndrome de Burnout (esgotamento profissional). Para Tamayo e Tróccoli (2002), a definição mais divulgada do burnout compreende esse fenômeno como uma síndrome psicológica, decorrente da tensão emocional crônica, vivenciada pelos profissionais, cujo trabalho envolve o relacionamento intenso e frequente com pessoas que necessitam de cuidado ou assistência. É um construto constituído pelas dimensões da exaustão emocional, da despersonalização e da diminuição da realização pessoal.

Contudo, mesmo diante desse cenário, Freitas (2007a) também enumera alguns pontos que remetem ao sentido, e às alegrias do trabalho docente, como a liberdade de expressão; a busca e o contato com outros universos de ideias, de autores, de lugares e de temas que favorecem uma rica vida interior e a aprendizagem; o contato com os pares; o reconhecimento proporcionado pelas aulas, debates, conferências, publicações e participação em congressos; autonomia e certo grau de liberdade, relacionados a um maior controle sobre o seu tempo, e o conteúdo da prática docente.

Para Bastos (2007), assim como se constata nas demais categorias ocupacionais, uma gama diversificada de valores e de significados atribuídos ao trabalho pode se encontrar na base da escolha pela docência e pesquisa. Para o autor, fatores motivacionais intrínsecos, como a realização, crescimento, servir à sociedade etc., combinam com fatores extrínsecos (remuneração, status, poder) no trabalho docente. Com relação às posturas competitivas, Bastos (2007) afirma que a comunidade acadêmica, a exemplo de quaisquer agrupamentos humanos, não se diferencia quanto às tensões da competição entre os seus membros. 
Nesse cenário de competição, valores diferenciados, cobranças por produção e qualificação, Bastos (2007) afirma ser desnecessário um amplo levantamento da literatura para se perceber que o trabalho docente, hoje, em todos os níveis em que ocorre, é fortemente associado a uma ameaça à saúde física e psicológica do trabalhador. Para Oliveira (2006), como forma de enfrentar o sofrimento psíquico, os professores desenvolvem estratégias singulares de defesa, como: excessiva submissão; resistência a todo tipo de mudança; baixo índice de envolvimento com o trabalho; psicossomatização; perda de percepção e consciência dos sérios problemas vivenciados no cotidiano da escola.

Apresentados os conceitos de cultura organizacional, e psicodinâmica do trabalho, é preciso frisar que dentro dos parâmetros de busca utilizados neste estudo não foram encontrados trabalhos que buscassem alguma relação entre a cultura organizacional das instituições de ensino às vivências de prazer e sofrimento no trabalho de docentes. Enfatizando essa relação entre cultura organizacional e vivências de prazer e sofrimento no trabalho, em toda a pesquisa de literatura, foi encontrado somente um trabalho, o de Garcia (2014), que aborda a relação entre a cultura organizacional e as vivências de prazer e sofrimento de trabalhadores de enfermagem. Assim, reforça-se o objetivo principal deste trabalho, que é o de analisar como a cultura organizacional se entrelaça às vivências de prazer e sofrimento no trabalho de professores de instituições federais de ensino superior.

Portanto, a partir dos elementos conceituais aqui apresentados, foi possível conduzir a pesquisa, conforme os procedimentos metodológicos detalhados a seguir.

\section{Procedimentos metodológicos}

A pesquisa emprega a abordagem qualitativa, visto que essa representa um meio pelo qual se pode entender o significado que se atribui a um problema social ou humano, isso aliado ao caráter multidisciplinar dos estudos organizacionais, em que diferentes modos de acesso e contextualização da realidade podem coexistir. Logo, busca-se por meio da pesquisa qualitativa uma descrição densa dos fatos, procurando a compreensão das experiências humanas 
dentro de determinado contexto (STAKE,1995; CRESWELL, 2010; GODOI; BALSINI, 2010; TAKAHASHI, 2013).

\subsection{Delineamento da Pesquisa}

A estratégia escolhida foi o estudo de caso, partindo-se de uma orientação interpretativista com base em Stake (1995). Os estudos de caso podem ser caracterizados pelo cunho interpretativo que requerem dos seus investigadores, pois o objetivo desse tipo de pesquisa é compreender uma situação em profundidade, enfatizando seu significado para os envolvidos (GODOY, 2010; STAKE,1995). Em especial, para esta pesquisa, a estratégia adotada caracteriza-se como estudo de caso múltiplo, por se tratar de um estudo que tem por objetivo analisar de maneira aprofundada o fenômeno social, não se limitando a um único caso (STAKE, 1995).

Com relação ao ambiente, a pesquisa caracteriza-se como pesquisa de campo, pois está voltada para o estudo de indivíduos, grupos, instituições entre outros campos, visando à compreensão de diferentes aspectos da sociedade. E ainda, em relação à dimensão do tempo, a pesquisa apresenta um corte transversal com aproximação longitudinal, visto que nos relatos dos fatos sempre há a possibilidade do resgate de experiências passadas para explicar um fenômeno presente (DENZIN; LINCOLN, 1994; STAKE, 1995).

\subsection{Técnicas de coleta e análise dos dados}

Os sujeitos da pesquisa foram 20 docentes de duas Instituições Federais de Ensino Superior - IFES, que apresentam um cenário similar de estrutura física entre elas, e estão localizadas na mesma região geográfica do Brasil. Esses docentes têm, em média, o grau de Doutor, 40 anos de idade, e 13 anos de experiência na atividade docente.

Para garantir o sigilo acerca da identidade dos docentes entrevistados, conforme compromisso firmado no momento da entrevista, os docentes receberam nomes fictícios. A escolha por dar nomes aos entrevistados deve-se ao cunho qualitativo desta pesquisa, que durante todo o tempo buscou o elemento humano desses profissionais, para além dos fatos referentes à sua carreira como docentes.

Considerando o caráter qualitativo da pesquisa, que permite o uso de variadas fontes de informações, os dados para este estudo 
foram coletados por meio de entrevistas semiestruturadas; de observação não participante; e de análise de documentos.

A escolha pela entrevista semiestruturada se dá pela ampla liberdade tanto ao entrevistador quanto ao entrevistado e, ao mesmo tempo, garante que todos os temas relevantes sejam tratados e todas as informações necessárias recolhidas, porém, isso só é possível quando os sujeitos são ouvidos a partir de sua lógica e exposição de razões (CORBETTA, 2003; GODOI; BALSINI, 2010; BREAKWELL, 2010).

Ainda sobre a coleta dos dados, a técnica da entrevista com frequência é combinada com a observação, pois, por meio da observação procura-se apreender o que os comportamentos dos sujeitos pesquisados podem revelar (GODOY, 2010). A observação feita durante as entrevistas levou em conta o estado emocional dos entrevistados, que por muitas vezes transitaram entre a forte emoção, o choro, e até mesmo a raiva, enquanto relatavam suas histórias.

Por fim, os dados foram tratados por meio da organização e transcrição das entrevistas, da organização dos documentos e relatórios da observação não participante, e posteriormente, analisados com base na análise de conteúdo de Bardin (2010). A análise de conteúdo emprega um conjunto de técnicas de análise das comunicações, visando obter, por procedimentos sistemáticos e objetivos de descrição do conteúdo das mensagens, indicadores (quantitativos ou não), que permitam a inferência de conhecimentos relativos às condições de produção/recepção dessas mensagens (BARDIN, 2010).

Assim, apresentam-se na sequência os resultados obtidos e as análises efetuadas, considerando os objetivos deste estudo.

\section{RESUlTAdOS DA PESQUISA E ANÁLISES CORRESPONDENTES}

Os resultados da análise de dados desta pesquisa estão sistematizados em: 1) Vivências de prazer e sofrimento no trabalho dos docentes; 2) Cultura organizacional e vivências de prazer e sofrimento no trabalho dos docentes, conforme apresentados a seguir.

\subsection{Vivências de prazer e sofrimento no trabalho dos docentes}

As vivências de prazer e sofrimento dos docentes referem-se, principalmente, ao relacionamento interpessoal, tanto com seus 
alunos, pares e chefias, os impactos do trabalho na vida pessoal, e social, além dos impactos do trabalho na saúde dos docentes. As vivências de sofrimento no trabalho também estão relacionadas com as formas de gestão, e outros elementos da cultura organizacional das instituições em que trabalham. Assim, a seguir são relatadas essas situações sob os enfoques específicos.

\subsubsection{Vivências de prazer e sofrimento no trabalho dos docentes com os alunos}

Constatou-se, nesta pesquisa, que as vivências de prazer no trabalho dos docentes estão principalmente vinculadas ao relacionamento com os alunos e às atividades desenvolvidas em sala de aula. Pôde-se perceber que os docentes, em sua maioria, criam um vínculo afetivo com os seus alunos, o que lhes proporciona sentimentos de realização, reconhecimento e prazer em desenvolver o seu trabalho, embora essa relação também traga vivências de sofrimento, como será relatado ao longo de todo este trabalho.

O trabalho, como fonte de prazer apoia-se fundamentalmente na premissa da atividade/trabalho como uma vivência de bem-estar. Assim, o trabalho fonte de prazer engloba as capacidades humanas de sentir, pensar e de fazer. O prazer no trabalho é sinônimo de felicidade, e modo de realização pessoal. A felicidade e a realização são indissociáveis dos sentimentos de contentamento, alegria, deleite e aprazimento que são vivenciados no ambiente de trabalho (FERREIRA, 2012).

Quando perguntados sobre o que lhes traz prazer no trabalho, a resposta dos vinte entrevistados foi unânime, citando a relação com os alunos como a sua maior fonte de prazer, embora, por vezes, essa mesma relação com os alunos traga alguns aspectos de desgaste. Algumas das falas dos docentes sobre a sua relação com os seus alunos estão transcritas a seguir.

Ser professor é muito bom, você nunca sai do mesmo jeito. É muito gratificante, é um aprendizado constante. (...) Nossa, eu participei disso! Um pouquinho do que ele é hoje, eu contribui. Isso se torna muito maior do que qualquer problema que a gente tenha, né! (Carla). 
A realização que os alunos nos proporcionam não tem dinheiro que pague! (Lucas).

(...) Oh professor! Isso é música para os meus ouvidos! Ser chamado de professor é música para os meus ouvidos! Isso não tem preço! (Lucas).

Ser reconhecido como professor me dá satisfação. A palavra professor estar atrelado ao meu nome, me dá prazer (José).

Esses relatos, quando analisados sob a ótica da Psicodinâmica do Trabalho, permitem compreender o trabalho como sendo um dos grandes alicerces de constituição do sujeito e de sua rede de significados. Para Dejours (2012), o reconhecimento tem um impacto considerável sobre a identidade. “É graças ao reconhecimento que uma parte essencial do sofrimento é transformada em prazer no trabalho" (DEJOURS, 2012, p. 367).

Contudo, caso o professor não perceba a oportunidade de experimentar um trabalho que proporcione autonomia, relações positivas com outros professores, funcionários ou estudantes, terá sua qualidade de vida no trabalho diminuída, podendo entrar em um quadro de sofrimento psicológico.

Nesse sentido, a relação com os alunos também pode levar a certo sofrimento, porém, esse sofrimento está relacionado ao questionamento que os docentes fazem sobre sua própria capacidade profissional. Esse sentimento vivenciado pelos docentes é definido por Dejours (2012) como o sofrimento gerado pelo medo de não satisfazer, de não atender às expectativas de certo público, no caso, dos alunos. Essas sensações são descritas a seguir, nas falas de Rosângela e José.

Quando os alunos não rendem, isso dá um sentimento de culpa, às vezes eu saio da aula arrasada, arrasada. Isso faz eu refletir que talvez a minha metodologia não esteja muito boa (Rosângela).

Nem sempre é tranquilo, existem turmas que a gente tem uma afinidade maior. Existem turmas em que essa correspondência não acontece. E isso desgasta muito fisicamente, psicologicamente, há um desgaste muito grande (José). 
Ainda sobre o sofrimento docente com relação aos alunos, há um relato sobre o assédio sexual sofrido por uma docente, por parte de seus alunos. Na literatura a respeito do sofrimento docente, há muitos relatos acerca de várias formas de violência por parte dos alunos contra os professores, porém, o assédio sexual é algo ainda pouco estudado. Sem dúvida, essa é uma situação que leva a docente a um sofrimento, como ela cita a seguir.

Por ser jovem já sofri preconceito por parte dos alunos. O assédio dos alunos também incomoda bastante. (...) Bem pejorativo. Essa é a pior parte. Assédio de aluno é triste, eles passam colando no meu corpo, mas eu não posso fazer nada, eu finjo que não aconteceu. Eu prefiro ignorar, até porque eu tenho medo deles me acusarem de perseguir a turma (Rosângela).

Encerrando essa seção sobre o prazer e sofrimento no trabalho dos docentes com os alunos, foi possível identificar que o grande fator de alegria e prazer para os entrevistados é a sua relação com os seus alunos. Contudo, essas relações também podem trazer sentimentos ruins, como o medo de não satisfazer, e até algumas situações pontuais como o assédio referido por Rosângela. Porém, infelizmente, os relatos de sofrimento no trabalho dos docentes entrevistados são bem mais numerosos do que os seus relatos a respeito de suas alegrias e realizações no seu trabalho.

As vivências de sofrimento no trabalho, relatadas pelos docentes nesta pesquisa, são muitas, e chama a atenção que a maioria das vivências de sofrimento dos docentes se referem ao relacionamento interpessoal com os seus pares e chefias, como será trazido a seguir.

\subsubsection{Vivências de sofrimento no trabalho dos docentes entre pares}

A respeito do aspecto emocional do trabalho, de acordo com Schujmann e Costa (2011), com o aumento das horas destinadas ao trabalho, caso bem específico dos docentes, o tempo de lazer está cada vez mais restrito e reduzido, o que dificulta na manutenção e no início de novos laços de amizade fora das instalações da empresa, o que possivelmente induz a um fortalecimento dos vínculos afetivos existentes dentro da organização. 
Assim, as interações e o surgimento de amizades no ambiente de trabalho podem ocupar um papel de destaque na vida das pessoas, uma vez que os amigos podem fornecer apoio, compreensão e ajuda. Contudo, perder um amigo no ambiente de trabalho significa deixar de ter uma fonte de apoio e ajuda. O rompimento de um relacionamento de amizade em uma organização pode ocorrer por vários motivos, entre eles as personalidades das pessoas, as expectativas conflituosas, as traições e as promoções (SCHUJMANN; COSTA, 2011).

Nos resultados obtidos nesta pesquisa, as relações interpessoais no contexto do trabalho dos docentes foram citadas como fontes de sofrimento no trabalho. Muitas situações que envolvem a falta de união entre os pares, e até mesmo as atitudes de competição, e falta de respeito entre eles foram relatadas durante as entrevistas. Essas situações são apresentadas nos relatos a seguir.

Nossos pares não são pares, são ímpares, são nossos ímpares! (Lucas).

Eu nunca tive uma relação com os meus pares do ponto de vista acadêmico (...) as discussões sempre foram guerras, e cada um defendendo a si mesmo, e as guerras sempre foram políticas. Existe muito mau caráter, muita mentira. Não existe uma relação. Nós não somos nem profissionais! (...) No meu curso tem professor processando o outro, processando o professor e a universidade que não tomou posição. Eu não posso xingar o meu colega em público, eu não posso escrever que meu colega é isso em um e-mail público, eu tenho que agir com urbanidade, eu sou um servidor público, eu tenho que cumprir a lei! (Lucas).

No relato de Lucas, fica claro seu incômodo sobre o fato de os docentes não manterem um ambiente de respeito entre si. Os fatos citados por ele, como os xingamentos e as difamações em público, vão além das relações interpessoais, e afetam o próprio código de ética desses profissionais, que devem cumprir a lei, agindo, no mínimo, com urbanidade entre si. Por isso, sua conclusão, de que "nós não somos nem profissionais", e o fato de Lucas incluir-se nessa fala reflete seu ponto de vista enquanto categoria, da qual ele faz parte. 
Ainda sobre essas situações de desrespeito e conflitos, o relato de Bruno reforça o quanto essas situações são prejudiciais.

Existe discriminação pela formação, entre os pares mesmo. Mas existe uma disputa já entre cursos, entre áreas, entre qualificações digamos assim. Vem questões pessoais, de vários níveis, de constrangimentos, de pessoas que não se conversam mais, que não se cumprimentam. Existe uma teia de relações que mistura o profissional com o pessoal (Bruno).

Para Elisa, a relação com os colegas de trabalho é descrita como péssima, e a causa disso, segundo ela, está na falta de diálogo entre os docentes, e também em um comportamento individualista, que não considera o grupo, ou o bem comum da instituição, mas sim, os interesses pessoais de cada um.

É péssima, lógico não é com todos. Tenho boa relação com alguns colegas, mas no geral é péssima. O diálogo não é produtivo, tem muita agressividade. (...) As discussões que temos em reuniões nunca são pelo/sobre o aluno, as discussões são porque eu quero menos horas, porque eu quero sair, eu quero afastamento, você tem menos coisas que eu (Elisa).

Gabriela, assim como Elisa, relata a sua decepção em estar em um ambiente acadêmico que não prioriza a construção do conhecimento, onde os interesses particulares prevalecem sobre o interesse coletivo, como revela na sua fala.

Estamos em um ambiente acadêmico, não pode acontecer esse tipo de coisa. O que mais me entristece é que não é pela construção do conhecimento, pela construção da universidade, é por cargo, por dinheiro, por interesses particulares. Aí você fica entristecido em função disso, isso deixa a gente assim desmotivado (Gabriela).

Para Rosângela, a convivência com os seus colegas docentes revelou-se problemática. Ela esperava uma relação mais participativa, e lamenta não poder desenvolver trabalhos com outros docentes. 
Também citou o preconceito que ela enfrenta pelo fato de sua formação não ser em licenciatura, como a maioria dos outros docentes, e que isso faz que ela se sinta excluída, como ela cita a seguir.

Existem as rixas, infelizmente elas existem. Quando eu comecei, eu pensei que eu não veria isso. Desenvolver um projeto em conjunto é praticamente impossível. Eu sinto falta dessa integração das áreas, e projetos em comum. Nas reuniões eu me sinto um pouco excluída (Rosângela).

A gente tem pensamentos diferentes, cada um fica numa bolha, aí nas reuniões a bolha deles é maior que a minha. Existe discriminação pela questão da formação. (...) Fica quieta aí porque a tua opinião não vale nada, eu sou licenciado e você não é! (Rosângela).

No depoimento de Vinícius, pode-se perceber mais traços do sofrimento psíquico que pode ser desencadeado nas relações interpessoais dos docentes, como o desgaste, a tristeza, e o abatimento.

Na avaliação do meu estágio probatório, um membro da equipe levou muito em consideração o que os alunos colocaram, não avaliou segundo o olhar dele, mas de acordo com o olhar dos alunos. Isso gerou um conflito imenso até hoje. A gente trabalha junto, mas tem esse conflito, isso não é bom, é desgastante. Eu levo pro pessoal muito, eu fico abatido, fico triste, fico desgastado psicologicamente, quando precisa trabalhar com aquela pessoa, você resgata todo o atrito anterior, e já começa a sofrer antes (Vinícius).

Na fala de Vinícius pode-se perceber o peso que o julgamento dos colegas sobre o seu trabalho tem para ele, a ponto de o fazer sofrer por antecedência, ao saber que terá que ter contato com colegas que não o consideram bem. Sobre os julgamentos, Dejours (1997) afirma que é a partir do julgamento que o sujeito recebe, que o indivíduo confere ao ego o reconhecimento pelo trabalho realizado. Para isso, é preciso que o indivíduo tenha maturidade para saber lidar com julgamentos negativos, a fim de não prejudicar sua 
autoconfiança e desestabilizar sua normalidade psíquica perante a sua atividade laboral.

Ao encerrar as considerações sobre as relações dos docentes entre pares, é importante destacar que, tão importante quanto os aspectos emocionais e afetivos, o aspecto organizacional mostra-se como um fator motivador para as vivências de sofrimento no trabalho dos docentes. Nos depoimentos trazidos, fica claro a falta de aplicação de normas e regras, que deveriam pautar o trabalho dentro das instituições (neste caso de estudo - públicas), de ensino, bem como, garantir um clima de trabalho respeitoso entre os pares.

Nesse sentido, Ferreira (2012) fala da importância de pensar o trabalho como fonte de prazer ou de sofrimento para os trabalhadores. Para o autor, torna-se um ponto interessante de reflexão para os dirigentes, e gestores das organizações, abrir espaço para a discussão dessas questões, para que se possa reconhecer e repensar os efeitos das organizações sobre a subjetividade dos indivíduos.

Além das vivências de sofrimento relacionadas com a convivência com os pares, os docentes também relatam vivências de sofrimento que resultam da sua relação com suas chefias diretas. Essas vivências de sofrimento são relatadas a seguir.

\subsubsection{Vivências de sofrimento no trabalho nas relações com as chefias}

Quanto às vivências de sofrimento advindas das relações entre os docentes e chefias, pode-se afirmar que essas foram as mais marcantes entre todas deste trabalho. Há que se citar que essas situações não ocorrem somente na relação vertical descendente (chefia/subordinados), mas também no sentido inverso (subordinados/chefia).

Ao iniciar esta seção, a fala de Lucas resume a relação entre docentes e chefias.

Professor não aceita a ideia de que alguém seja o chefe dele, não aceita a ideia de ter um chefe imediato. Ele acha que ninguém pode ser o chefe imediato dele, porque ele se acha! (...) Só tem cacique aqui! (Lucas). 
É uma universidade de balcão. Ninguém manda, ninguém obedece. Ninguém cumpri ordem, porque cumprir ordem denigre a minha imagem... ah pelo amor de Deus! (Lucas).

Retomando o objetivo principal deste trabalho, uma das reflexões que se busca provocar é a percepção de como os elementos da cultura organizacional no contexto deste caso, uma organização pública, com as suas regras, normas, valores, comunicação, discurso, poderiam contribuir para a mudança de tais cenários dentro destas instituições.

Destaca-se portanto, no relato de Lucas, a falta de procedimentos, normas e regras, quando se refere a "uma universidade de balcão" "Ninguém manda", "ninguém obedece" "ninguém cumpri ordem". Além disso, na fala de Lucas pode-se perceber alguns dos traços da cultura organizacional brasileira, quando ele se refere às pessoas que "fazem descaradamente as coisas para beneficiar a si mesmo e a outros". Nessa fala, é possível perceber a presença do personalismo permeando as relações de trabalho dentro da instituição.

Para que se possa ter uma noção de quanto sofrimento essas relações mal estabelecidas entre docentes e chefias podem gerar, são trazidas algumas histórias detalhadas. A primeira história é a de Gabriela. Para contextualizar o cenário dessa história, é preciso esclarecer que Gabriela já tinha experiência como docente em outras instituições, e quando entrou na instituição pesquisada, propôs algumas sugestões para o curso onde atuava, contudo, essa postura de Gabriela gerou uma situação que, segundo ela, foi de assédio moral.

Eu como tinha experiência na área do curso fiz algumas propostas, e os outros professores do curso não gostaram, e começaram alguns enfrentamentos, muito maléficos! (...) Essas coisas começaram a me incomodar muito, eu até falo que eu tive o meu filho antes, por causa de todas essas questões (Gabriela).

O meu filho nasceu com seis meses e meio, por tudo isso. Aquelas pessoas não são gente, não são gente, é assédio moral o que fizeram comigo. Fui muito assediada por eles, E eu sentia que era tudo para me afrontar, diziam que eu não fazia as coisas, que fazia fora do prazo. Eu não dormia, não podia tomar remédio para dormir, porque 
eu estava grávida, eu tinha muita dor no pescoço de tensão, eu tinha febre, ficava sem voz, não conseguia dar aula, falava e não saía a voz, assim direto, direto, direto. (...) Nisso rompeu o tampão, e eu entrei em trabalho de parto, e ai eu me afastei definitivamente. Mesmo assim ele nasceu de seis meses e meio, ficou 40 dias na UTI, mas hoje está bem. Mas foi todo um sofrimento, nesse período eu pedi remoção para outro curso, pensei até em sair da instituição! (Gabriela).

Nesse relato de Gabriela, é possível uma análise sob o enfoque da psicodinâmica do trabalho, no que se refere às expressões diretas do sofrimento, como a insônia, as dores no corpo, ocasionadas pela tensão, a falta de voz, chegando ao extremo da quase perda do seu bebê, em decorrência de todos os problemas físicos e psicológicos enfrentados no trabalho.

Gabriela, ao final da sua entrevista, ainda fez o seguinte comentário:

É um desabafo poder falar um pouco do que nos incomoda, mas também nos faz feliz! Falar sobre a saúde mental no trabalho, o quanto determinado tipo de cultura pode ser prejudicial. Não existe uma preocupação institucional sobre isso (Gabriela).

Outra situação é a de Elisa, que relata sua experiência com sua chefia imediata. Elisa sofreu uma perseguição pessoal, que lhe trouxe vários problemas, desde a dificuldade em realizar seu doutorado, sua separação, e diversos problemas de saúde.

Eu sofri muito quando aconteceu porque foi um ataque pessoal. Foi quando eu pedi para fazer doutorado (presencial), e eu pedi afastamento. Aí infelizmente, quando eu pedi afastamento, mas quatro professores da minha área solicitaram afastamento também. Realmente eu entendo que é complexo dar o afastamento para quatro pessoas, ao mesmo tempo, só que as outras três pessoas conseguiram, e eu não! Sendo que eu fui uma das primeiras professoras a chegar, com mais tempo de instituição, e mais produção acadêmica (Elisa). 
A história de Elisa não terminou com a negativa de afastamento para o doutorado. Durante a realização do mesmo, ela continuou a ter problemas com a sua chefia, como descrito no seu relato.

Mas depois disso eu enfrentei um processo administrativo porque essa pessoa (referindo-se à coordenação) me acusou de abandono do trabalho. Ela falava que eu estava viajando, sendo que eu não estava viajando, sem autorização dela (Elisa).

(...) Eu tive que pedir para os alunos assinarem um documento de que eu estava presente em todas as aulas. Tudo isso, mais cursar o doutorado me levou a uma separação, psicólogo, voltei a fumar, fazia dez anos que não fumava, voltei a fumar, pedi a transferência, e eu não queria mais entrar na instituição. Não era que não queria, eu não conseguia. Tentava atravessar o prédio e começava a chorar, e se eu não tivesse tratado isso com o psicólogo, hoje possivelmente também não estaria aqui hoje... (Elisa).

Elisa continua o seu relato sobre o processo administrativo que teria sido aberto contra ela.

Eu acho que jamais abriram o processo, foi só a questão do assédio mesmo, eu acho isso trágico. E isso não aconteceu só comigo, aconteceu com outras pessoas do centro. (...) O coordenador do centro tem um comportamento que é agressivo mesmo, aconteceu com muitas outras pessoas, não assim, mas das pessoas se sentirem ofendidas, de assédio moral (Elisa).

A respeito do assédio moral, Freitas (2007c) afirma que é na vida psicossocial do sujeito, vítima dessa violência, que o assédio surtirá os seus efeitos negativos, com o impacto na sua personalidade, identidade, e autoestima. Segundo a autora, o assédio gera desordens na vida psíquica, social, profissional, familiar e afetiva do indivíduo, provocando diversos problemas de saúde, particularmente os de natureza psicossomática, de duração variável, que desestabilizam a sua vida. Essas desordens reduzem a capacidade de concentração do indivíduo, induzem-no ao erro e colocam em 
risco tanto o seu emprego como a sua vida. Entre esses riscos estão a depressão, os pensamentos autodestrutivos, e as tentativas de suicídio (FREITAS, 2007c).

Com base nos depoimentos de Gabriela e Elisa, pôde-se perceber que a pior consequência que esse relacionamento desastroso entre os docentes e suas chefias pode trazer é o sofrimento, que leva ao adoecimento, e até mesmo a situações extremas de desespero. No relato de Lucas, será possível identificar quantos malefícios as pessoas podem causar umas às outras, em suas relações profissionais. O relato de Lucas traz a questão do assédio moral que parte dos subordinados para com as chefias, pois Lucas relata a sua experiência como chefia, como coordenador de curso.

O pior erro que eu cometi foi ter assumido um cargo! Eu entrei com muita vontade e meti a cabeça com tudo. E lutei por isso. Tive muitos projetos aprovados, publicações. E ali já começou a ter esse desgaste. (...) Eu levava muito pra casa. Coordenar professores é horrível, porque você não tem como mandar ele fazer, eles diziam: não, não tem como fazer hoje, eu não consigo (...) Então eu pegava e fazia. Pra eu cumprir os prazos eu fazia, isso foi acumulando (Lucas).

Eu comecei a somatizar, em abril de 2014 foi a gota d'água, foi quando eu senti que estava perdendo o controle. Muita cobrança, e aí já qualquer motivo era motivo para eu me sentir daquela forma, era uma angústia constante, não tinha um momento em que eu não estivesse angustiado, eu estava sempre triste, muito angustiado, eu não conseguia mais raciocinar parecia que tudo que eu fazia estava errado, coisas mínimas começaram a se tornar muito pesadas (Lucas).

Eu fui para o psiquiatra em setembro de 2014, o médico me diagnosticou com transtorno de ansiedade generalizada depressiva. E na hora ele disse você tem que sair do teu trabalho. Eu estava sozinho, e o trabalho me acabando. Mas o médico disse se você não seguir o tratamento você pode ter um colapso (Lucas).

E aí eu comecei a fazer o tratamento, às vezes eu estava bem, chegava no trabalho eu começava a ter pavor de chegar na instituição, na hora 
que eu ia chegando meu coração já ia disparando, eu já ia suando frio, então eu rezava para não encontrar ninguém na porta (Lucas).

Antes de abrir e-mail, até hoje é assim, ainda me dá um friozinho na boca do estômago, porque eu recebi e-mails terríveis, grosseiros (Lucas).

Comecei tomando sertralina, frontal, comecei com o frontal $0,50 \mathrm{mg}$ foi pra $1 \mathrm{mg}, 1,5 \mathrm{mg}, 2 \mathrm{mg}$, quando ia acabando o efeito eu ficava alucinado, não foi nem uma nem duas vezes que eu pensei em suicídio. A angústia era uma coisa tão terrível, a minha família se revezava para me cuidar porque a gente mora no $5^{\circ}$ andar, aquilo era tão terrível, que eu pensava assim, olha eu acho que a morte não é tão dolorosa quanto isso (Lucas).

Lucas estava muito emocionado, e chorou muito nesse momento ao lembrar esse período difícil que enfrentou. Lucas disse que agora consegue falar sobre isso, mas essas lembranças ainda trazem bastante sofrimento para ele.

Para Ferreira (2012), os fatores associados aos atos de suicídio em virtude do trabalho estão relacionados principalmente com um forte sentimento de pressão; com a realização de trabalho isolado, reduzindo e empobrecendo as relações socioprofissionais no trabalho; com práticas de não reconhecimento no trabalho; e o suporte organizacional ausente, ou precário.

Para Dejours e Deranty (2010), o suicídio no local de trabalho traz um significado muito forte, e não deixa de ser uma mensagem direcionada aos colegas de trabalho, às chefias, e às próprias instituições. É possível que se permita um nível de sofrimento tão grande dentro das instituições de ensino, e outras organizações em geral? Essa é uma das muitas reflexões que este trabalho busca trazer.

Foram 5 meses para eliminar o frontal, mudei a medicação aí eu fui melhorando. (...) Eu não vou dizer que eu estou curado porque eu não estou ainda. É um processo muito doloroso (Lucas). 
Antes de relatar toda a sua história, quando perguntado se ele realmente queria falar sobre isso, Lucas disse algo que é de extrema importância para o contexto das instituições, não só as de ensino, mas as organizações em geral.

Eu acho necessário falar sobre isso, eu acho que precisa de estudos como esse, que sejam publicados, porque as universidades estão matando os seus funcionários, professores e taes, nós estamos vivendo uma agressão física, não é só intelectual, é física, é na carne, porque quando você está sofrendo uma agressão em uma reunião, que não é uma agressão física é verbal, mas você não está só sentindo angústia, você está sentindo dor, o teu estômago dói, os teus órgãos estão te comendo, tua cabeça tá doendo, o nervoso é tão grande que as tuas veias estão doendo (Lucas).

Ao encerrar esta seção sobre o prazer e sofrimento no trabalho dos docentes, relacionados com a convivência entre alunos, pares e chefias, é preciso frisar que, além das relações no trabalho, percebe-se que as relações pessoais desses docentes também são influenciadas por suas vivências de sofrimento no trabalho. Essas vivências de sofrimento também se relacionam com a vida familiar e vida social dos docentes. Esse tema é tratado a seguir.

\subsubsection{Vivências de sofrimento relacionadas à vida familiar e social}

$\mathrm{O}$ excesso de trabalho foi relatado pela maioria dos docentes. Esse excesso de trabalho manifesta-se não só nas atividades de docência realizadas em casa, durante o tempo livre, como feriados ou finais de semana, mas também na questão do trabalho onipresente, ou seja, o trabalho estar o tempo todo permeando o pensamento dos docentes, até o ponto de prejudicar as vivências de lazer, ou o convívio com pessoas da família ou outros grupos sociais. Nesse sentido, para Araújo et al. (2016), o sofrimento psíquico vivenciado pela pessoa em seu espaço de trabalho reflete em todas as áreas de sua vida, no relacionamento familiar, com os amigos e, principalmente, em sua saúde física e mental.

Para exemplificar essas situações, alguns depoimentos são trazidos a seguir. 
Muitas vezes eu perdi festas, tive problemas com a esposa pelo excesso de trabalho (Sérgio).

No exame admissional eu tive uma recomendação médica para fazer atividade física. Isso durou 10 meses, por que eu abandonei? Por conta do trabalho. No meu noivado, eu tive um momento de crise, por causa do trabalho (José).

(...) Ela ia no banheiro, eu ia para o computador, ela ia preparar alguma coisa, eu aproveitava para corrigir duas provas, porque eram duas a menos. Foi quase a perda de uma relação de marido e mulher. Hoje eu levanto cedo no final de semana. Por que? Pra trabalhar! Enquanto ela dorme eu estou fazendo alguma coisa. Eu percebo que o prejuízo é de relação social mesmo, relação com o ente amado. Então quando eu estou com ela, eu tento aproveitar. Não sei até que ponto eu vou conseguir levar assim, eu acho que não vai ser muito não (José).

Assim como no depoimento de Sérgio, no relato de José chama atenção sua preocupação com a relação entre ele e a esposa. Sobre as relações familiares e sociais, Ferreira et al. (2013) apontam os muitos prejuízos sociais como fruto das longas jornadas de trabalho, como a falta de acompanhamento e a presença emocional dos pais para com os filhos, casais que se separam pelo distanciamento, e pela irritação frequentes, nos lares onde marido e mulher pouco se encontram, e quando isso acontece, ambos estão cansados, e intolerantes.

Nos depoimentos a seguir, ficam evidentes situações em que o excesso de trabalho levou a prejuízos ou perdas, de ordem familiar ou social, como a perda de amigos, o isolamento social, o distanciamento dos filhos, e até mesmo a separação.

Sim, eu não saia de casa, no final de semana não era lazer, era para colocar as coisas em dia. Meu marido quer que eu saia, minha mãe quer que eu vá para a casa dela. Mas eu tenho prova para corrigir, aulas para planejar. Aí as pessoas falam, ah você vive para essa universidade, você só fala na universidade, você está muito chata, você tá muito chata! E a gente não percebe. Quase perdi as amizades que eu tinha, uma amiga disse que meu marido era uma pessoa muito boa para 
me aguentar (...) Eu não tenho chamado você para sair, para tomar uma cervejinha porque você tá muito chata! Aí foi que eu percebi, ou eu mudo, ou eu vou perder todo mundo (Gabriela).

Eu me separei. Quando eu estava casada, eu reclamava muito do trabalho. Mas eu acho que não foi o principal motivo da separação, mas sempre afeta. Porque consome energia, então você está sempre cansada, esgotada, sem vontade de fazer nada, sair (Fernanda).

Sim, tem prejuízos, às vezes você está tão cansado, que até você gostaria de visitar alguém, mas aí você tá tão cansado que você prefere ficar em casa para dormir, descansar. Prejudica sim (Mário).

Sobre esses depoimentos, cita-se a reflexão de Menezes, Nepomuceno e Batista-dos-Santos (2011), que afirmam que o trabalho do professor não é executado apenas no lugar de trabalho, isso decorre, sobretudo, da flexibilidade de horários que seu trabalho permite, existindo tarefas que são realizadas em casa. A flexibilidade de horário já foi analisada sob a ótica do prazer emergente no discurso, mas uma análise mais aprofundada das falas parece apontar que decorrente da flexibilidade do horário existe um trabalho onipresente, ou seja, o que é trabalho para o professor não fica apenas no ambiente de trabalho, no contexto visível da "gaiola de ferro", tornando-se quase impossível para eles separar a vida no trabalho da vida fora dele. Isso também faz que o trabalho dos professores seja muitas vezes exigente e causador de sentimentos como tensão e angústia, sentimentos esses que parecem derivados do desprazer (MENEZES; NEPOMUCENO; BATISTA-DOS-SANTOS, 2011).

Nesse mesmo sentido, para Viera (2014), os professores estão imersos em um conflito cotidiano entre o que é exigido, o que desejam, e o que realmente é possível fazer diante dos obstáculos, das condições e da organização atual do trabalho. O sofrimento psíquico, vivenciado pelos professores, é manifestado por meio de sinais e sintomas expressos em desânimo, fadiga, frustração, estresse, depressão, impotência, insegurança, irritabilidade, angústia e, até mesmo, "sensação de enlouquecimento". Muitas vezes, os fatores que potencializam esse sofrimento são as relações hierárquicas, a 
longa e exaustiva jornada de trabalho, a dificuldade de estabelecer o "controle da turma", o crescente rebaixamento salarial e, principalmente, a progressiva desqualificação e o não reconhecimento social de seu trabalho (VIEIRA, 2014).

Sobre a saúde dos docentes desta pesquisa, percebe-se que esta também é afetada pelos impactos do excesso de trabalho, e das relações interpessoais desastrosas. Esse tema será abordado a seguir.

\subsubsection{Vivências de sofrimento dos docentes e impactos na saúde}

Seguem os depoimentos dos docentes sobre suas experiências de doenças, físicas ou emocionais, vivenciadas em decorrência do trabalho. Bruno ressalta o quanto o contexto da instituição contribui para o sofrimento dos docentes no trabalho.

É um ambiente muito árido, muito hostil. E consequentemente leva as pessoas a um certo distanciamento. Eu estou com vários colegas em tratamento, não só na terapia, mas com medicamentos, alcoolismo. Esse ambiente precipita o que há de melhor e o que há de pior nas pessoas. Cada pessoa tem uma forma de reagir. Emocionalmente me deu uma balançada. O fato de ir pra terapia. O ambiente me leva aos extremos. É uma montanha-russa emocional. Por mais que eu goste de mudança, todo mundo precisa de uma estabilidade. A Instituição nos leva a esse ambiente de instabilidade constante. É um lugar que nos leva a sempre estar num limite. Em 2013 eu estive perto de uma síndrome de pânico. Aí eu comecei a terapia (...) Então tem colegas assim já tendo que tomar medicamentos, afastados. O pior de tudo é o burnout, leva as pessoas a terem um desvirtuamento de comportamento. Isso vai nos afetar, se o ambiente já tá ruim, ele vai ficar pior. Isso vai nos levar a uma guerra de todos contra todos (Bruno).

Bruno mostra a sua preocupação com os efeitos que o contexto da instituição ainda poderá trazer sobre a saúde de todos que ali trabalham, como um alerta. No depoimento de Jéssica, ela também enfatiza como o contexto da sua instituição reforça os sintomas de sua doença, já preexistente. 
Eu tenho fibromialgia. Quando eu fico ansiosa, ou muito estressada, eu não fico legal. Eu tenho um problema de fadiga muito grande. Quando acontece algum problema, e isso afeta o meu trabalho, no fim do dia eu vou estar acabada, não quero fazer nada, não quero ver minha família, só quero ficar quieta, não vou sair com amigos, nesse sentido, com certeza afeta (Jéssica).

Logo que eu entrei na Instituição, depois de um mês os problemas de fibromialgia voltaram, bem piores do que na primeira vez. Era uma sobrecarga absurda por causa de coisas desorganizadas. A minha fibromialgia tem relação com a ansiedade. Demorar para dormir, batimentos acelerados, sintomas que são emocionais mas não de depressão (Jéssica).

A respeito dos relatos de doenças do trabalho, Faria e Meneguetti (2007) descrevem os sintomas das doenças exercendo uma espécie de punição sobre o corpo, manifestada na intensificação do ritmo de trabalho, na rotinização das tarefas, no acúmulo de horas de trabalho, entre outros muitos fatores. No caso das doenças psicossomáticas, como o estresse, depressão, neuroses e obsessões diversas, estas também resultam em doenças físicas, de diversas ordens, como as úlceras causadas pelo nervosismo, as enxaquecas, os problemas vasculares, entre outros.

Para Sérgio e Fernanda, são os problemas decorrentes do cansaço físico que se tornam fonte de sofrimento no trabalho.

Eu trabalhava demais, isso me causou um problema muito sério, eu me tornei hipertenso, tinha picos de pressão que me faziam apagar. Cheguei a desmaiar em sala de aula, e acordei no hospital (Sérgio).

Era um cansaço, dificuldade de acordar. Eu tinha vontade de chorar do nada, ou por qualquer coisa, ficar em casa, não sair, estava beirando a depressão. Eu tentava fazer o que eu conseguia, eu ia só para a aula, tinha reuniões e eu não ia. Eu comecei a tentar me cuidar, reduzir minha carga horária. Eu tive que lidar com essa dificuldade de querer fazer tudo certinho, eu comecei a priorizar a minha saúde. Você sabe o que é chorar de cansaço? Eu chorava de cansaço (Fernanda). 
Sobre as análises do prazer e sofrimento no trabalho docente, pôde-se perceber como as relações interpessoais influenciam essas vivências dos docentes. E, além de serem prejudiciais ao trabalho desenvolvido por eles, elas se propagam para além do contexto do trabalho, refletindo também nos aspectos da vida social e familiar dos docentes, e principalmente, tendo impactos na sua saúde física e mental. Nesse sentido, pôde-se perceber que o contexto do trabalho e as formas de gestão das instituições pesquisadas também contribuem para esses processos de adoecimento e sofrimento no trabalho. Em vista disso, a seguir, é tratada a questão da cultura organizacional das instituições, dos elementos e traços da cultura que os docentes percebem, e que estão entrelaçados às suas vivências de sofrimento no trabalho.

\subsection{Cultura organizacional e vivências de prazer e sofrimen- to no trabalho dos docentes}

Como citado no referencial teórico desta pesquisa, a cultura organizacional reflete um conjunto complexo e multidimensional de tudo o que constitui a vida em comum nos grupos sociais. Seria ainda um conjunto de modos de pensar, de sentir e de agir, mais ou menos formalizados, os quais, tendo sido aprendidos e sendo partilhados por uma pluralidade de pessoas, servem de maneira ao mesmo tempo objetiva e simbólica, e passam a integrar essas pessoas em uma coletividade distinta de outras. É o resultado de ações cujos componentes e determinantes são compartilhados e transmitidos pelos membros de um dado grupo (PIRES; MACÊDO, 2006).

Ainda, de acordo com Pires e Macêdo (2006), as organizações públicas mantêm as mesmas características básicas das demais organizações, acrescidas, entretanto, de algumas especificidades, como: o apego às regras e rotinas, a supervalorização da hierarquia, o paternalismo nas relações, o apego ao poder, entre outras. Para contextualizar essas situações, seguem os depoimentos dos docentes com suas percepções sobre a cultura organizacional das instituições em que trabalham.

Bruno descreve a cultura e as práticas organizacionais que, segundo ele, são prejudiciais à saúde física e emocional de todos os que lá trabalham. 
A instituição é um ambiente extremamente repressor, com um nível de indiferença gigantesco, vai gerando uma anomia, a anomia é uma desarticulação das ações, até chegar no suicídio. Eu acho que na instituição, o pessoal acha que é um termo forte, mas eu acho que a gente caminha para um suicídio. É uma relação muito complexa, de amor, de ódio, de estranhamento, é muito humano. É uma universidade performática. $\mathrm{O}$ ambiente como o da instituição te leva a uma provação constante. Você fica extremamente exposto e testado constantemente. Leva a um desgaste total. À exaustão, ou o burnout que eu acho que já tá acontecendo ai (Bruno).

(...) A instituição não valoriza, parece que faz juízo de valor sobre o trabalho das pessoas, de gerar anomia, gerar indiferença, ou gerar sarcasmo digamos assim, ou deboche em relação ao que tá fazendo (Bruno).

A questão da valorização do trabalho citada por Bruno vem ao encontro da reflexão de Dejours (1997) sobre a questão do reconhecimento. Para o autor, as considerações a respeito do reconhecimento e valorização do trabalho permitem compreender como o julgamento do trabalho pode funcionar na subjetividade dos indivíduos. $\mathrm{Na}$ perspectiva de uma teoria do fator humano, este ponto é essencial: o reconhecimento é a forma específica da retribuição moral e simbólica dada ao ego, como compensação por sua contribuição à eficácia da organização do trabalho (DEJOURS, 1997).

Nesse sentido, Bruno continua seu relato sobre a indiferença percebida no seu trabalho.

Um clássico da instituição é a indiferença. Um ambiente totalmente indiferente. $\mathrm{O}$ cara tá se matando ai, deixa lá, nós estamos ficando insensíveis em geral. O que eu chamo de falta de diálogo. A metáfora que eu uso, que a Instituição tem nos levado é de exílio. Tem gente exilada aqui. É um ambiente de sofrimento. Eu acho que o trabalho não precisa ser um ambiente de sofrimento. É quase um ambiente de autopunição. É um ambiente assim que as pessoas estão num limite. A instituição tá perdendo o encanto. Eu tô com medo da gente cair 
naquela coisa assim, ah tem que fazer, vamos fazer. Aquela coisa assim sem envolvimento (Bruno).

Fabrício também enfatiza, na sua narrativa, a questão da gestão da instituição não colaborar para uma mudança do cenário de trabalho.

A principal injustiça que eu vejo aqui, que eu sinto é a falta de gestão. Não se cobra para que a universidade vá para frente. Isso eu acho muito injusto. Há pessoas que não querem assumir sua responsabilidade, outros que ficam sobrecarregados (Fabrício).

Nos relatos seguintes são trazidas as questões da falta de regulamentação e normatização das atividades docentes e a falta de democracia nas decisões das instituições de ensino pesquisadas.

A falta de meritocracia no ambiente organizacional. Não vejo como isso pode ser mudado, não vejo solução para isso. E outra, a falta de regulamentos, normas mais claros, mais respaldo (Jéssica).

Decisões muito verticalizadas. O que mais me incomoda é a falta de respaldo legal para as minhas ações. Normas específicas. Não sou legalista, nem formal, mas precisamos de amparo legal! (Gabriela).

Nos relatos de Jéssica e Gabriela, é possível perceber o quanto a falta de regulamentação específica, para elas é algo que traz uma sensação de insegurança quanto às suas ações. Para José, a falta de um ambiente democrático, a burocracia excessiva, por parte da gestão e os comportamentos descomprometidos dos colegas, trazem para ele um sentimento de frustração, pois para ele é impossível formar os alunos com uma visão diferenciada, quando o ambiente institucional não contribui para isso.

O sentimento é de que a gente não consegue formar por completo. Eu não consigo argumentar com o meu aluno que a universidade dele é democrática, conseguir viver aqui um exemplo de democracia, um lugar onde as pessoas podem e conseguem construir coletivamente 
algo, isso é o que mais me incomoda, assim, essa incapacidade de transpor de alguma forma esse modelo da nossa sociedade. Mas eu não consigo fazer com que eles percebam isso aqui. Porque as chefias não são escolhidas, são nomeadas (José).

Além da cultura organizacional, e dos aspectos da gestão das instituições percebidos pelos docentes, os entrevistados citaram também os elementos da cultura organizacional que identificam no seu cotidiano de trabalho. A fala de Jéssica remete a esses elementos, como as regras e normas, a comunicação, e o discurso das instituições. Os elementos da cultura organizacional são detalhados a seguir.

Faltam regras e normas. A comunicação, o discurso não condiz com a realidade. Deveria ter condições institucionais mais organizadas para dar esse apoio. (...) Injustiças nas nomeações, não por mérito, acontece muito, muito, muito, isso eu já nem dou bola mais. Na distribuição de aulas, isso também afeta, quem bate o pé mais forte sempre leva. A chefia não quer criar atrito, e aí quem grita mais consegue mais (Jéssica).

\subsubsection{Elementos da cultura organizacional percebidos pelos docentes}

Um dos elementos da cultura organizacional, percebidos e citados pelos entrevistados, foi a comunicação. De acordo com Marchiori (2008), a cultura e a comunicação são aspectos indissociáveis de uma realidade organizacional, pois a cultura organizacional se forma a partir do momento em que as pessoas se relacionam, e se elas se relacionam, estão se comunicando.

A comunicação interna eu acho péssima. Eu acho que tem um grupo de privilegiados que fica sabendo de todas as informações, e a gente fica sabendo sempre por terceiros. A informação não segue um fluxo. Eu coloquei isso em uma reunião, que eu fico muito triste com isso. Quem trabalha em determinados setores são privilegiados por terem certas informações. Falta de uma lisura institucional para enviar comunicados (e-mails informais demais), falta uma formatação para isso 
(...) Estou sabendo que... (coisa de fofoca). Gente isso é uma instituição, que comunicação é essa? (Gabriela).

Essa comunicação é filtrada. Nem todos ficam sabendo das decisões (Carlos).

Outro elemento muito citado foram as normas e regras das instituições. Sobre esses elementos, Freitas (2007b) afirma que toda a cultura organizacional é ancorada em maneiras de fazer as coisas, que influenciam os seus membros. Assim, as normas e regras definem o comportamento esperado, aceito ou apoiado pelo grupo, seja ele explícito formalmente ou não.

Algumas das percepções dos docentes sobre as regras e normas de suas instituiçõoes são apresentadas a seguir.

As regras até existem, são meio contraditórias, mas existem. É uma instituição que nega a regra, como uma forma de rebeldia, mas também não propõe outra coisa. O que eu acho pior não é a regra, mas ter a regra e não ser seguida. Tá no papel, mas não funciona. Isso na instituição para mim é o problema central (Bruno).

Não tem normas, as que tem são malfeitas, então não precisa ter jeitinho para burlar norma, é só chegar e falar com alguém (Bruno).

Sobre regras e normas, de acordo com Freitas (2007b), as culturas são criadas, apoiadas, sustentadas e transmitidas por meio da interação social, via processos de modelagem, imitação, negociação, reprodução de histórias, e informações sobre as normas e regras, nos seus aspectos formais e informais. Assim, pode-se dizer que todos os artefatos culturais estão ligados entre si, exercendo uma influência múltipla no conjunto dos indivíduos, e dos grupos integrantes da organização. Quando a cultura é bem cuidada, existe certo grau de consistência interna entre esses diversos elementos, contudo, quando a mensagem passada por meio de um artefato é contraditória ou negada por outro, gera-se confusão e insegurança. Desse modo, um dos fatores que causam algumas das aprendizagens mais relevantes 
no cotidiano organizacional diz respeito ao saber sobre o que é a regra, e o que é a exceção.

Outro elemento da cultura organizacional citado foi o discurso das instituições. De acordo com Faria e Meneghetti (2007), o discurso está presente em todas as esferas da vida social, tendo um papel extremamente importante no ambiente organizacional. $\mathrm{O}$ discurso pode criar uma dimensão capaz de estabelecer regras de comportamentos, de condutas e de diálogos comuns a uma classe social, um grupo social, ou à sociedade em geral, aceita por todos e legitimado como padrão de conduta a ser adotado. Os discursos podem ser vinculados pela linguagem falada ou escrita, e ainda pela mídia ou pelos meios de comunicação internos das organizações (FARIA; MENEGHETTI, 2007).

As diferenças percebidas entre o discurso e a realidade das instituições estão presentes nos relatos a seguir.

Nós temos um discurso muito afiado, bonito, engajado, moderno, contemporâneo, inovador. É um lugar muito maluco. Você tem uma proposta de integração, e uma prática de segmentação (Bruno).

O discurso não condiz com a realidade. Existe um grupo de professores que quer transformar a instituição em uma universidade burguesa como todas as outras (Gabriela).

O discurso não condiz com a realidade. Os alunos são prova disso, eles vêm imaginando uma coisa e se deparam com outra (Lucas).

É diferente sim. A instituição precisa parar de vender algo que ela não tem (Carla).

Assim, além dos elementos da cultura organizacional percebidos pelos docentes, como a comunicação, as normas e regras, e o discurso organizacional, alguns traços da cultura brasileira estariam presentes no cotidiano das instituições, de acordo com os depoimentos dos entrevistados. Esses traços são explicados a seguir. 


\subsubsection{Traços da cultura organizacional brasileira percebidos pelos docentes}

Freitas A. B. (1977), quando se refere a traços brasileiros, fala de características gerais que podem ser comuns ou frequentes na maioria dos brasileiros. "Esses traços são como parte inconsciente de cada indivíduo, sendo que alguns podem parecer mais nítidos para alguns, outros nem tanto" (FREITAS, A. B., 1997, p. 39).

Especificamente quanto ao setor público, esse é percebido como um terreno onde predominam o apadrinhamento político, as relações de favorecimento pessoal e os privilégios que contornam as normas formalmente instituídas. O sentimento de iniquidade e injustiça, bem como, a incongruência entre o discurso e as práticas oficiais, produz frustração em relação aos projetos pessoais e profissionais, levando à desmotivação e dificultando a formação de expectativas positivas quanto às possibilidades de mudança (PIRES, MACÊDO, 2006).

Nesse sentido, o relato de Bruno exemplifica o personalismo e o autoritarismo que ele percebe na instituição em que trabalha.

Na prática, nós somos conservadores, reprimidos. Parece que nós temos pouca tradição democrática. Democracia é você ter um espaço de diálogo. A instituição não é um lugar democrático, é um lugar verticalizado, um lugar com padrinhos, um lugar de conchavos, de carreirismo, de autoritarismo, manda quem pode, obedece quem tem juízo! (Bruno).

As pessoas vivem em determinados grupos e se protegem naqueles grupos. Pra quem pensa igual a mim tudo, pro outro, aí vem a lei. O Brasil é um país autoritário. Parece que a instituição vem incorporando isso. Uma visão assim, a não ser que mexa comigo, o resto eu não quero nem saber... (Bruno).

A instituição não tem uma visão coletiva. É uma visão bastante fragmentada por interesses, os mais diversos. A instituição se apropriou dessa cultura, ficou o ethos, eu te dou um jeito. Uma espécie de uma oligarquia. Eu tenho um discurso democrático, mas se você não é meio amigo, eu vou te cozinhando aqui... (Bruno). 
Nos relatos a seguir, o personalismo também é percebido como um traço da cultura organizacional presente no ambiente de trabalho.

Se você tem amizades, você tem tudo, você consegue as coisas. Eu nunca precisei. Mas aqui acontece bastante. Ocupar chefias por exemplo (Rosângela).

Porque as pessoas usam o poder para prejudicar uma pessoa?! Isso aí desgasta mais, magoa mais. Quando você não faz isso, você não é do círculo de aliados, você está fora do sistema. E se você está fora do sistema, você vai ter que lutar contra ele. Tudo é mais difícil. Porque eles mexem de acordo, para você isso, pra você aquilo. Aqui as regras são assim! (Elisa).

A instituição tem muito essa coisa de perseguição, porque qualquer coisa que você fale, a pessoa acha que é contra ela. A instituição é personalista, as pessoas não agem pela sua competência. Tipo, eu não sou a professora que quer alguma coisa. Eu sou a Elisa que quer alguma coisa, e se eu tenho algum problema com a Elisa, eu vou atacar ela. Isso eu falo porque já aconteceu comigo (Elisa).

De acordo com Barros e Prates (1996), o personalismo expressa a importância atribuída às pessoas e aos interesses pessoais, em detrimento das pessoas ou interesses do grupo ou comunidade. Indica, ainda, o alto grau de confiança depositado na rede de amigos e familiares para resolução de problemas ou obtenção de privilégios. O personalismo é claramente definido na expressão popular "para os amigos tudo, para os inimigos nada, para os indiferentes a lei". Assim, de acordo com os autores, a aplicação restrita da lei é reservada apenas ao cidadão anônimo, isolado e sem relações (BARROS; PRATES, 1996).

Para Freitas, A. B. (1997), o personalismo se reflete principalmente na esfera pública, onde, muitas vezes, a escolha de pessoas que exercerão funções públicas faz-se de acordo com critérios de relações pessoais e não de suas capacidades. Os relatos a seguir evidenciam essa situação. 
Claro que sim! As amizades, o patrimonialismo personalista tem sim. Apadrinhamentos nas bancas de processos seletivos de professores. Distribuição de aulas, tem professor que fala que não vai dar aula, e não acontece nada! (Gabriela).

O curso $\mathrm{X}$ tem mais professores do que alunos, e aí vieram questionar uma substituição no meu curso pelo princípio da economicidade. Dois pesos e duas medidas. Um curso que não precisa de professor pode abrir um concurso, e uma vaga no meu curso fere o princípio da economicidade?! Mas por quê? Porque o curso X é constituído por homens, o diretor é do curso, claro que tem uma questão aí. E do outro lado sou eu, a Gabriela, quem é ela? (Gabriela).

Usar o cargo como uma força política, para ganhar um parceiro político, eu já vi também. Indicam-se cargos meio às portas fechadas, ninguém entende porque não faz sentido, e na verdade é só para conseguir apoio político de uma demografia, ou de um grupo. Isso me incomoda! (Jéssica).

Outro traço da cultura brasileira que apareceu no relato dos docentes refere-se ao jeitinho. Sobre esse assunto, DaMatta (1991) define o jeitinho como a maneira original que o brasileiro tem de harmonizar a regra às práticas da vida diária. No entender de DaMatta (1991), o jeitinho é uma forma de articular as exigências da lei às necessidades e desejos de cada um, em cada momento. $\mathrm{O}$ indivíduo tem como espaço a rua, onde cada um se torna desconhecido e as regras valem para todos. Já na casa, as relações de familiaridade, amizade e vizinhança estabelecem diferenças entre cada um, frente aos demais. O jeitinho seria uma articulação entre esses dois universos, a casa e a rua, um jeito ou estilo original do brasileiro de viver, e às vezes de sobreviver, e principalmente um papel social a ser utilizado nos momentos em que as leis oferecem obstáculos às expectativas de cada um (DaMATTA, 1991; MATHEUS, 1997).

O jeitinho é conhecido e citado por todos os entrevistados como um traço presente na cultura organizacional. Todas as pessoas entrevistadas conhecem situações onde se aplica o jeitinho, assim como conhecem e utilizam a expressão "jeitinho brasileiro", ou 
"dar um jeitinho", como forma de resolver uma situação difícil ou proibida, sob a forma de burlar alguma regra ou norma estabelecida. Seguem alguns relatos sobre o jeitinho nas instituições pesquisadas.

Ah mais a gente dá um jeito! Não há controle de nada, tudo pode acontecer (Gabriela).

Cada um dá seu jeito da forma que lhe convém, usando daquilo que tem. A gente começa a cair em contradição. Você começa a perder seus referenciais, você vai ganhando nesse jogo, que nos leva a naturalizar. A instituição vem naturalizando isso com padrinhos, esse jeitinho, mesmo questionando. Falta coleguismo, falta decoro. Falta ouvir o outro (Bruno).

Ao encerrar a seção sobre cultura organizacional, elementos e traços da cultura percebidos no contexto de trabalho, é importante salientar que os traços e características da cultura organizacional de organizações públicas aqui apresentados não se aplicam necessariamente a todas as organizações públicas no Brasil, não devendo ser, portanto, generalizados a priori, como destacam Pires e Macêdo (2006).

De acordo ainda com os mesmos autores, sabe-se que a cultura tende a se perpetuar, e que só pode ser transformada por meio de um processo de construção social. Os projetos para mudanças e intervenções, caso sejam de interesse do poder público, que deveriam representar as aspirações da sociedade organizada, teriam de necessariamente abordar aspectos estruturais, normativos e enfocar os trabalhadores, com sensibilizações e com mecanismos que assegurassem a continuidade dos projetos, pois só por meio das pessoas se transforma uma sociedade (PIRES; MACÊDO, 2006).

Nesse mesmo sentido, Chu e Wood (2008) afirmam que alguns traços culturais brasileiros, como o personalismo e o jeitinho, podem ser de fácil observação. Outros, porém, podem exigir experiências e olhares mais aprofundados. No entanto, a compreensão dos sistemas culturais é essencial para orientar a ação gerencial, evitar frustrações e viabilizar a implantação bem-sucedida de projetos transformacionais. 


\section{Considerações finais}

Como objetivo geral, a pesquisa buscou analisar como a cultura organizacional se entrelaça às vivências de prazer e sofrimento no trabalho de professores de Instituições Federais de Ensino Superior. Tal problematização foi motivada pela escassez de estudos sobre as relações entre a cultura organizacional e seus elementos, com as vivências de prazer e sofrimento dos trabalhadores. Quanto à motivação prática desta pesquisa, essa se deu pela observação dos processos de adoecimento de docentes de uma universidade federal, sendo esses processos de adoecimento, em sua maioria, de fundo emocional ou psíquico, levando a um alto número de afastamentos do trabalho.

$\mathrm{Na}$ análise dos dados obtidos, evidenciou-se que a atividade docente traz em si várias características que propiciam vivências de prazer para os docentes, como o contato com o universo das ideias e temas que trazem uma rica experiência interior, a possibilidade de reconhecimento e admiração por parte dos alunos, e a possibilidade de poder contribuir para o crescimento das pessoas, da construção de algo em prol do bem comum, e de contribuição para a sociedade.

Esses relatos dos docentes vão ao encontro das necessidades de reconhecimento, e de sentido para o trabalho realizado, de acordo com Dejours (2007). Assim, o reconhecimento no trabalho pode ser decisivo para a construção da identidade dos sujeitos, pois o trabalho se inscreve na dinâmica da realização do ego. Entretanto, não podendo gozar os benefícios do reconhecimento de seu trabalho, nem alcançar o sentido de sua relação para com o trabalho, o sujeito se vê reconduzido ao sofrimento. O sofrimento, por sua vez, é capaz de desestabilizar a identidade e a personalidade, e de levar à doença mental.

De acordo com os dados obtidos por meio das entrevistas com os docentes, o sofrimento no trabalho é favorecido quando as relações interpessoais com alunos, pares e chefias tornam-se difíceis. Como consequência desses conflitos interpessoais estão o distanciamento, a desconfiança, o medo, a raiva, e inevitavelmente, a doença.

Os processos de adoecimento relatados pelos docentes vão desde o desgaste físico e mental até situações extremas como a depressão, os transtornos de ansiedade, e a intenção suicida. Sobre o des- 
gaste no trabalho, Ferreira (2012) refere-se às formas de exigências físicas sob os dispêndios fisiológicos requeridos dos trabalhadores. No caso dos docentes, essas exigências se revelam sob a forma de postura, gestos, deslocamentos, emprego da voz, prejuízos do sono, entre outras, que levam ao cansaço, e aos sintomas físicos, como as dores, a falta de voz, as doenças vasculares, gástricas, encefálicas, e do sistema nervoso em geral.

Ferreira (2012), ainda, cita as exigências do trabalho, sob os aspectos cognitivos, e afetivos do sujeito. Nas falas dos docentes, esses aspectos se revelam no desgaste emocional, na falta de atenção, memória, do custo da tomada de decisão, e das reações afetivas como a raiva e o medo, o estado de humor alterado, atitudes agressivas, e até mesmo, comportamentos violentos.

A análise das vivências de sofrimento dos docentes evidenciou também os conflitos e prejuízos nas relações familiares e sociais, devido à sobrecarga de trabalho. Entre esses prejuízos foram relatados o isolamento, a falta de tempo para atividades de lazer, o distanciamento nas relações amorosas e familiares.

A cultura organizacional e seus elementos estiveram presentes em praticamente todas as falas dos entrevistados. Para os docentes, as fontes de sofrimento estão relacionadas também ao contexto das instituições de trabalho, e às formas de gestão dessas instituições. Foram citados os aspectos da falta de experiência dos gestores, a falta de organização administrativa, o sentimento de não reconhecimento, a vivência de injustiça e iniquidade, as tensões entre equipes, o desenvolvimento do individualismo, como consequências da cultura organizacional, e do modo de gestão das instituições.

Quanto aos elementos da cultura organizacional destacados pelos docentes, no contexto de uma organização pública, estão a comunicação, as regras e normas, e o discurso organizacional. Esses elementos se entrelaçam às suas vivências de prazer e sofrimento no trabalho, pois por meio deles a organização do trabalho pode ser influenciada, manipulada, ou até mascarada, instaurando um clima de insegurança, desconfiança, o que pode levar aos processos de adoecimento, ou agravar as situações já existentes.

Também foram percebidos pelos docentes alguns traços, ou características, da cultura organizacional brasileira, como o personalis- 
mo, o autoritarismo, e o jeitinho, presentes no cotidiano do trabalho das instituições pesquisadas. Esses traços também contribuem para as vivências de sofrimento no trabalho dos docentes entrevistados.

Ao final deste trabalho, concluiu-se que quando a cultura organizacional permite o aprendizado, o crescimento, e o desenvolvimento do potencial de trabalho, as relações interpessoais saudáveis, e valores que refletem autonomia, bem-estar, ética, preocupação com a coletividade, os efeitos são positivos para as vivências de prazer no trabalho. Contudo, quando a cultura organizacional não reflete tais condições, e se mostra permissiva a situações de injustiça, perseguições, atitudes antiéticas, falta de autonomia, disputas entre grupos, entre outras, os efeitos são negativos, levando ao sofrimento e favorecendo o adoecimento no trabalho.

De acordo com Ferreira et al. (2013), a cultura organizacional deve ser capaz de sustentar políticas e práticas que envolvam a participação de todos os membros organizacionais, que permitam a contribuição do trabalhador, e estejam vinculadas a práticas mais amplas de gestão de pessoas, capazes de modificar o contexto de produção, e a própria organização do trabalho.

Assim, a partir deste estudo foi possível perceber a necessidade de uma mudança de mentalidade, sobretudo de dirigentes e gestores, para removerem valores, crenças, e práticas do contexto organizacional, que podem estar na origem dos problemas que levam ao sofrimento e adoecimento no trabalho. De acordo com Ferreira (2012), um novo modelo de gestão organizacional deve se pautar na promoção do reconhecimento, e valorização dos trabalhadores, criar oportunidades iguais para o crescimento profissional, estimular a criatividade e a autonomia na execução das tarefas, fomentar relações profissionais saudáveis no trabalho, além de disponibilizar as condições físicas adequadas para o trabalho. “Tais condições não são uma panaceia para todos os males organizacionais, mas cumprem uma função de nortear o processo de implantação de bases sólidas que propiciem eliminar, ou mitigar, os riscos de adoecimento no trabalho" (FERREIRA, 2012, p. 282).

Assim, espera-se que as reflexões feitas pelos docentes de graduação neste trabalho, assim como os seus depoimentos, chamem a atenção para esse tema tão sério para o contexto das organizações, 
e que promovam mudanças reais nas práticas organizacionais. Pois, acredita-se que as organizações exercem influência cada vez maior sobre as condutas individuais, sobre a natureza, as estruturas socioeconômicas e a cultura, o que as leva a se transformar em elementos-chave das sociedades, contribuindo dessa forma para edificar uma ordem social mundial (CHANLAT, 2013).

\section{REFERÊNCIAS}

ALCADIPANI, R.; CRUBELLATE, J. M. Cultura Organizacional Brasileira: Generalizações Improváveis e Conceituações Imprecisas. RAE - Revista de Administração de Empresas. São Paulo, v. 43, n. 2, abr./jun. 2003.

ALTHUSSER, L. Concepções sobre o trabalho. In: KANAANE, R. Comportamento humano nas organizações: o homem rumo ao século XXI. São Paulo: Atlas, 1994.

ARANTES, I. C. S. Aproximações Teórico-metodológicas entre a Psicodinâmica do Trabalho, a Sociologia Clínica e a Análise Crítica do Discurso: Repensando Possibilidades Onto-epistêmicas para a Pesquisa em Administração. In: ENANPAD XXXIX, 2015. Belo Horizonte. Anais... Belo Horizonte, 2015.

ARAÚJO, et al. Psicodinâmica do Trabalho e Qualidade de Vida no Trabalho (QVT): Duas Faces da Mesma Moeda? Pesquisa ação em uma Organização do Governo Brasileiro. In: ENANPAD, XL, Costa do Sauípe. Anais... Costa do Sauípe, 2016.

AUGUSTO, M. M.; FREITAS, L. G.; MENDES, A. M. Vivências de prazer e sofrimento no trabalho de profissionais de uma fundação pública de pesquisa. Psicologia em Revista. Belo Horizonte, v. 20, n. 1, p. 34-55, 2014.

BARDIN, L. Análise de conteúdo. Lisboa: Edições 70, 2010.

BARROS, T.; PRATES, M. O estilo brasileiro de administrar. São Paulo: Atlas, 1996.

BASTOS, A. V. B. O ofício acadêmico: singular ou plural? Revista O\&S, Salvador, v. 14, n. 43, p. 179-185, 2007.

BERGER, P. L.; LUCKMAN, T. A construção social da realidade: tratado de sociologia do conhecimento. Petrópolis: Vozes, 1998.

BRANT, L. C.; GOMEZ, C. M. A transformação do sofrimento em adoecimento: do nascimento da clínica à psicodinâmica do trabalho. Revista Ciência \& Saúde Coletiva, v. 9, n. 1, p. 213-223, 2004.

BREAKWELL, G. Métodos de entrevista. In: BREAKWELL, G.; HAMMOND, S.; FIFE-SCHAW, C; SMITH, J. A. Métodos de pesquisa em Psicologia, 3 ed. Porto Alegre: Bookman, 2010.

CHANLAT, J. F. Por uma antropologia da condição humana nas organizações. In: CHANLAT, J. F. (Coord.). O indivíduo na organização: dimensões esquecidas, 3. ed. São Paulo: Atlas, 2013, $1 \mathrm{v}$. 
CHU, R. A.; WOOD, T. J. Cultura organizacional brasileira pós-globalização: global ou local? Revista de Administração Pública - RAP. Rio de Janeiro, v. 42, n. 5, p. 969-91, 2008.

CORBETTA, P. Social research: theory, methods and techniques. London: Sage, 2003.

CRESWELL, J. W. Projeto de pesquisa: métodos qualitativo, quantitativo e misto, 3. ed. Porto Alegre: Bookman, 2010.

DAMATTA, R. O que faz do Brasil, Brasil? 5. ed. Rio de Janeiro: Rocca, 1991.

DEJOURS, C. A banalização da injustiça social. Trad. Luiz Alberto Monjardim. Rio de Janeiro: Editora Fundação Getúlio Vargas, 2007.

DEJOURS, C. A carga psíquica do trabalho. In: DEJOURS. C; ABDOUCHELI, E.; JAYET, C. Psicodinâmica do trabalho: contribuições da escola dejouriana à análise da relação prazer, sofrimento e trabalho. São Paulo: Atlas, 2012.

DEJOURS, C. A loucura do trabalho: estudo de psicopatologia do trabalho, 5. ed. São Paulo: Cortez-Aboré, 1992.

DEJOURS, C. O fator humano. Trad. Maria Irene Stocco Betiol, Maria José Tonelli. Rio de Janeiro: Editora Fundação Getúlio Vargas, 1997.

DEJOURS, C. Subjectivity, work, and action. Critical Horizons, v. 7, n. 1, p. 45-62, 2006.

DEJOURS, C. Uma nova visão do sofrimento humano nas organizações. In: CHANLAT, J. F. (Coord.). O indivíduo na organização: dimensões esquecidas, 3. ed. São Paulo: Atlas, 2013, 1 v.

DEJOURS, C.; ABDOUCHEL, E. Itinerário teórico em psicopatologia do trabalho. In: DEJOURS. C; ABDOUCHELI, E.; JAYET, C. Psicodinâmica do trabalho: contribuições da escola dejouriana à análise da relação prazer, sofrimento e trabalho. São Paulo: Atlas, 2012.

DEJOURS, C.; ABDOUCHELI, E.; JAYET, C. Psicodinâmica do trabalho: contribuições da escola dejouriana à análise da relação prazer, sofrimento e trabalho. São Paulo: Atlas, 2012.

DEJOURS, C.; DERANTY, J. P. The centrality of work. Critical Horizons, v. 11, n. 2, p. 167$180,2010$.

DENZIN, N. K.; LINCOLN, Y. S. Handbook of qualitative research. Sage, 1994.

FARIA, J. H.; MENEGHETTI, F., K. Discursos organizacionais. In: FARIA, J. H. (Org.). Análise crítica das teorias e práticas organizacionais. São Paulo: Atlas, 2007.

FERREIRA, et al. Qualidade de vida no trabalho: questões fundamentais e perspectivas de análise e intervenção. Brasília: Paralelo, 2013.

FERREIRA, M. C. Qualidade de vida no trabalho. Uma abordagem centrada no olhar dos trabalhadores, 2. ed. Brasília: Paralelo 15, 2012.

FERREIRA, M. C.; MENDES, A. M. "Só de pensar em vir trabalhar, já fico de mau humor": atividade de atendimento ao público e prazer sofrimento no trabalho. Estudos de Psicologia, Universidade de Brasília, v. 6, n. 1, p. 93-104, 2001. 
FISCHER, T.; MAC-ALLISTER, M. Jogando com cultura organizacional. In: CLEGG, S; HARDY, C; NORD, W. R. Handbook de estudos organizacionais, v. 2. São Paulo: Atlas, 2001.

FLEURY, M. T. L.; FISCHER, R. M. Cultura e poder nas organizações, 2. ed. São Paulo: Atlas, 1996.

FREITAS, A. B. Traços brasileiros para uma análise organizacional. In: MOTTA, F. C. P; CALDAS, M. P. Cultura Organizacional e Cultura Brasileira. São Paulo: Atlas, 1997.

FREITAS, M. E. A carne e os ossos do ofício acadêmico. Revista O\&S, Salvador, v. 14, n. 42, p. 187-191, 2007a.

FREITAS, M. E. Cultura organizacional: evolução e crítica. Ed. Cencage Learning, 2007b.

FREITAS, M. E. Cultura organizacional: formação, tipologias e impactos. São Paulo: Makron, McGraw-Hill, 1991.

FREITAS, M. E. Cultura organizacional: identidade, sedução e carisma? Ed. FGV, 2006.

FREITAS, M. E. Quem paga a conta do assédio moral no trabalho? RAE-eletrônica, v. 6, n. 1 , art. 5, jan./jun. 2007c.

GARCIA, A. B. Cultura organizacional e vivências de prazer e sofrimento no trabalho de profissionais de enfermagem de um hospital filantrópico do interior do estado de São Paulo, 108s. Dissertação (Mestrado em Administração) - Escola de Enfermagem de Ribeirão Preto, Universidade de São Paulo, Ribeirão Preto, 2014.

GEERTZ, C. A Interpretação das Culturas, 1. ed. Rio de Janeiro: LTC Editora, 1989.

GODOI, C. K.; BALSINI, C. P. V. A pesquisa qualitativa nos estudos organizacionais brasileiros: uma análise bibliométrica. In: GODOI, C. K.; BANDEIRA-DE-MELLO, R.; SILVA, A. B. Pesquisa qualitativa em estudos organizacionais: paradigmas, estratégias e métodos. São Paulo: Saraiva, 2010.

GODOY, A. S. Estudo de caso qualitativo. In: GODOI, C. K.; BANDEIRA-DE-MELLO, R.; SILVA, A. B. Pesquisa qualitativa em estudos organizacionais: paradigmas, estratégias e métodos. São Paulo: Saraiva, 2010.

HOLANDA, S. B. Raízes do Brasil. São Paulo: Companhia das Letras, 1989.

MARCHIORI, M. et al. Faces da cultura e da comunicação organizacional, 2. ed. São Paulo: Difusão Editora, 2008.

MATHEUS, T. C. Inverno social: uma discussão psicanalítica sobre o imaginário da lei no Brasil. In: MOTTA, F. C. P.; CALDAS, M. P. Cultura Organizacional e Cultura Brasileira. São Paulo: Atlas, 1997.

MENDES, A. M. Aspectos psicodinâmicos da relação homem trabalho: as contribuições de C. Dejours. Psicologia: Ciência e Profissão, v. 15, n. 1. Brasília, 1995.

MENDES, A. M. Vivências de prazer sofrimento no contexto organizacional, 306. Tese. Universidade de Brasília, Brasília, 1999.

MENDES, A. M., ABRAHÃO, J. I. A influência da organização do trabalho nas vivências de prazer e sofrimento dos trabalhadores: uma abordagem psicodinâmica. Psicologia Teoria e Pesquisa, v. 26, p. 179-184, 1996. 
MENDES, A. M.; AGUIAR, V. B. Por uma gestão mobilizadora de qualidade de vida no trabalho. A proposta da clínica psicodinâmica do trabalho. In: FERREIRA, et al. Qualidade de vida no trabalho: questões fundamentais e perspectivas de análise e intervenção. Brasília: Paralelo, 2013.

MENDES, A. M.; TAMAYO, A. Valores organizacionais e prazer sofrimento no trabalho. Psico-USF, v. 6, n. 1, p. 39-46, 2001.

MENEZES, L. M.; NEPOMUCENO, L. H.; BATISTA-DOS-SANTOS, A. C. Os sentidos do trabalho para um grupo de professores de uma universidade pública: a dialética prazer sofrimento em tempos de flexibilidade. In: ENANPAD XXXV, 2011. Rio de Janeiro. Anais... Rio de Janeiro, 2011.

MORGAN, G. Imagens da organização. São Paulo: Atlas, 1998.

MOTTA, F. C. P.; CALDAS, M. P. Cultura Organizacional e Cultura Brasileira. São Paulo: Atlas, 1997.

OLIVEIRA, E. S. G. O. Mal-estar docente como fenômeno da modernidade: os professores no país das maravilhas. Revista Ciências \& Cognição, Rio de Janeiro, v. 7, p. 27-41, 2006.

PEÇANHA, D. L. N. Cultura Organizacional e Saúde - contribuições da Psicodinâmica do Trabalho. Boletim Academia Paulista de Psicologia, v. 77, n. 2, 329-344, 2009.

PIRES, J. C. D. S.; MACÊDO, K. B. Cultura organizacional em organizações públicas no Brasil. Revista de Administração Pública, v. 40, n. 1, p. 81-105, 2006.

ROCHA, S. R. A.; MENDES, A. M; MORRONE, C. F. Sofrimento, distúrbios osteomoleculares e depressão no contexto de trabalho: uma abordagem psicodinâmica. Estudos e Pesquisas em Psicologia. Rio de Janeiro, v. 12, n. 2, p. 379-394, 2012.

SCHUJMANN, A.; COSTA, S. G. Amizade no local de trabalho. In: VAZQUEZ, A. C. S.; BASTIANELLO, M. R. In: COSTA, S. G. Psicologia aplicada à administração. São Paulo: Elsevier, 2011.

STAKE, R. E. The art of case study research. Sage, 1995.

TAKAHASHI, A. R. W. Pesquisa Qualitativa em Administração. São Paulo: Atlas, 2013.

TAMAYO, M. R.; TRÓCCOLI, B. T. Burnout no trabalho. In: MENDES, A. M.; BORGES, L. O.; FERREIRA, M. C. Trabalho em transição, saúde em risco. Universidade de Brasília, Brasília, 2002.

VAZQUEZ, A. C. S.; BASTIANELLO, M. R. In: COSTA, S. G. Psicologia aplicada à administração. São Paulo: Elsevier, 2011.

VIEIRA, S. R. S. Sofrimento psíquico e trabalho. Revista Latinoam. Psicopat. Fund. São Paulo, v. 17, n. 1, p. 114-124, 2014.

Recebido em: 07-03-2017

Aprovado em: 30-8-2017

Avaliado pelo sistema double blind review.

Editor: Elmo Tambosi Filho

Disponível em http://mjs.metodista.br/index.php/roc 